\title{
FULL-TEXT ARTICLES FROM ORAL PRESENTATIONS
}

\begin{abstract}
Transcriptomic Meta-Analysis in Pancreatic Ductal Adenocarcinoma Reveals Therapeutic Targets and Diagnostic Biomarkers
\end{abstract}

\section{[Transkriptomik Meta-Analiz ile Pankreatik Duktal Adenokarsinomada Terapötik Hedefler ve Diagnostik Biyobelirteçlerin Belirlenmesi]}

Sevcan ATAY, Ph.D.

Ege University Faculty of Medicine, Department of Medical Biochemistry, Bornova, Izmir, Turkey

\section{Corresponding Author:}

Sevcan ATAY, Ph.D

Assistant Professor of Biochemistry

Department of Medical Biochemistry

Ege University Faculty of Medicine

Bornova, Izmir 35100 Turkey

Phone: +90 232390 4089, Email: sevcan.atay@hotmail.com

\section{ABSTRACT}

BACKGROUND: Pancreatic ductal adenocarcinoma (PDAC) is the most common form of pancreatic cancer, which has the highest mortality rate of all solid tumors. The absence of an effective screening process and distinctive symptoms causes a delay in diagnosis. Traditional chemotherapy and curative surgery have limited benefits on patient survival. Enzymes are one of the most important groups of drug targets and are preferred markers for the detection of various diseases.

OBJECTIVES: This study aims to identify up-regulated genes encoding enzymes in PDAC to suggest novel therapeutic targets for more effective treatments to be developed and diagnostic biomarkers for PDAC.

MATERIALS and METHODS: NCBI Gene Expression Omnibus (GEO) was searched for datasets using keywords 'pancreatic ductal adenocarcinoma'. The inclusion criteria were i) Gene expression microarray data, ii) human-derived pancreatic ductal adenocarcinoma tissues and normal pancreatic tissue samples. All data processing and integration procedures were performed using ExAtlas. The false discovery rate is less than 0.05 , and the change of gene expression is $\geq 10$-fold were considered significant. The up-regulated enzyme-coding genes were detected in the differentially expressed gene list. The identified upregulation of enzyme-coding genes in PDAC was verified using datasets from TCGA and GTEx projects.

RESULTS: The random effect integrative meta-analysis of five submissions (GSE46234, GSE19280, GSE43795, GSE41368, and GSE71989) containing 24 tumor-normal tissue pairs revealed 22 up-regulated genes, two of which encoding enzymes. The enzyme-coding genes with at least 10-fold differential expression compared to the controls were SULF1 (sulfatase, fold change=22.135) and KYNU (kynureninase, fold change $=10.716$ ), in consistence with the results from TCGA and GTEx data.

CONCLUSIONS: The results of this study suggest that sulfatase and kynureninase may have the potential to become diagnostic biomarkers and therapeutic targets for PDAC, which merits further investigation.

Keywords: Pancreatic Ductal Adenocarcinoma, microarray, meta-analysis, enzymes, gene expression

\section{ÖZET}

Genel Bilgi: Pankreatik duktal adenokarsinoma (PDA), en yaygin pankreas kanseri türü olup tüm solid tümörlerde en yüksek ölüm oranına sahiptir. Etkili bir tarama prosesinin ve ayırıcı semptomlarının bulunmayışı tanıda geç kalınmasına neden olmaktadır. Geleneksel tedavi yöntemleri ve küratif cerrahinin hastaların yaşam oranlarında sağladığı iyileşme oldukça kısıtlıdır. Enzimler, ilaç hedeflerinin önemli bir grubunu oluşturmakta olup aynı zamanda birçok hastalığın tanısinda tercih edilen belirteçlerdir.
Amaç: Bu çalışma, PDA'da daha etkili tedavi yöntemlerinin geliştirilmesi için yeni terapötik hedefler ve diagnostik biyobelirteçler önermek amacıyla enzim-kodlayan ve PDA'da yüksek eksprese olan genleri tanımlamayı amaçlamaktadir.

Gereç ve Yöntemler: NCBI Gene Expression Omnibus (GEO) veri bankası 'pankreatik duktal adenokarsinoma' anahtar kelimesi kullanılarak tarandı. Çalışmanın inklüzyon kriteri; i) Gen ekspresyon microarray datası, ii) insan kaynaklı PDA ve normal pankreatik doku örneklerini içeren çalışmalar olmasıdır. Tüm veri işleme ve entegrasyon prosedürleri ExAtlas kullanılarak yapıldı. Meta-analiz, random effects metodu kullanılarak gerçekleștirildi. FDR oranının 0.05 'ten az olması ve gen ifadesindeki değişimin $\geq 10$ kat olması istatistiksel olarak anlamlı kabul edildi. Ekspresyonu yükselmiş olan enzim kodlayan genler ekspresyonları farklılaşmış gen listesinde tespit edildi. PDA'da tanımlanan enzim-kodlayan genlerin yüksek ekspresyonu TCGA ve GTEx projelerinden elde edilen veri setleri kullanılarak doğrulandı.

Bulgular: Totalde beş GEO veri setinden 24 tümör-normal doku çiftinin dahil edildiği rastgele etki bütünleştirici meta-analizi, ile PDA'da 22 yüksek eksprese olan gen belirlenmiştir. Kontrollere kıyasla en az 10 kat diferansiyel ekspresyonu olan enzim kodlayan genler, TCGA ve GTEx verilerinin sonuçları ile uyumlu olduğu bulunan, SULF1 (sülfataz 1, kat değişimi = 22.135) ve KYNU (kinüreninaz, kat değişimi $=10.716$ ) olarak belirlenmiştir.

Sonuç: Bu çalışmanın sonuçları, sülfataz 1 ve kinüreninazın PDA'da diagnostik biyobelirteç ve terapötik hedef olma potansiyellerine sahip olabileceğini göstermektedir.

Anahtar Sözcükler: Pankreatik duktal adenokarsinoma, mikroarray, meta-analiz, enzim, gen ekspresyonu

\section{INTRODUCTION}

Pancreatic cancer (PC) is a highly fatal malignancy and the fourth common cause of death from cancer within all types of tumors [1]. Pancreatic ductal adenocarcinoma (PDAC) and its variants are the most common types of pancreatic cancer and constitute more than $90 \%$ of all cases [2]. The overall 5 -year survival rate for patients with pancreatic cancer remains less than $8 \%$ and a one-year survival is around $18 \%$ when all stages are combined $[1,3]$. Pancreatic cancer is asymptomatic in early stages; thus, the majority of patients with pancreatic cancer present at advanced stages. Besides, the absence of an effective screening process contributes to the resulting delayed diagnosis [4, 5]. Over $50 \%$ of patients with pancreatic cancer are diagnosed at the metastatic stage of the disease, and approximately $85 \%$ of these patients have a survival rate of less than one year [6]. Patients with metastatic state of the disease cannot benefit from surgical resection improving median overall survival to 11-23 months [7]. Even after radical resection, $60 \%$ of the patients experience local and systemic relapse within the first 12 months after curative resection [8], and more than $80 \%$ of the patients die of the disease due to local recurrence and/or distant metastasis [9]. Thus, early diagnosis of PDAC remains challenging and current therapeutic modalities are still inadequate in the treatment of the disease. There is an urgent need for the identification of diagnostic biomarkers and the development of novel and effective targeted therapies.

High transcriptome profiling is one of the most utilized approaches in the identification of novel prognostic or diagnostic biomarkers, and the development of more effective therapeutic targets. With the increasing number of studies using high transcriptome profiling, integration of transcriptome data by combining microarray raw data from several studies has become a preferred method to increase sample size, statistical power, and reliability for studies aiming to find novel biomarkers. Several meta-analyses have been conducted to determine molecular and clinical subtypes of pancreatic cancer [10], and to identify novel prognostic [11-14] or diagnostic biomarkers [15]. Using an integrative high transcriptome meta-analysis approach, this study aims to identify up-regulated enzyme-coding genes in PDAC and to suggest novel diagnostic biomarkers and therapeutic targets for the disease.

\section{MATERIAL and METHODS}

\section{Selection of Microarray Datasets}

NCBI Gene Expression Omnibus (http://www.ncbi.nlm.nih.gov/geo/) was systematically searched for eligible datasets using the keywords 'pancreatic ductal adenocarcinoma'. Inclusion criteria were: $i)$ Gene expression microarray 
XXVII. Balkan Clinical Laboratory Federation Meeting BCLF 2019

XXX. National Congress of the Turkish Biochemical Society TBS 2019

data, ii) studies included human-derived pancreatic ductal adenocarcinoma tissues and normal pancreatic tissue samples.

Generation of Gene Expression Matrix Files and Evaluation of Data Quality All data processing and integration procedures were performed using ExAtlas according to the manual of the software [16]correlation matrix,gene set enrichment,ANOVA,PCA,expected proportion of false positives $</$ keyword $><$ / keywords $><$ dates $><$ year $>2015<$ year $><$ /dates $><$ accession-num $>26223199<$ / accession-num $><$ urls $><$ related-urls $><$ url $>$ https://www.worldscientific.com/ doi/abs/10.1142/S0219720015500195 $<$ /url $></$ related-urls $></$ urls $><$ electronicresource-num $>10.1142 / \mathrm{s} 0219720015500195</$ electronic-resource-num $><$ / record $></$ Cite $></$ EndNote $>$. The datasets that have been selected for meta-analysis were uploaded to ExAtlas and then gene expression matrix file was generated from each dataset separately. All the extracted data were pre-normalized with the RMA algorithm. Samples, where the correlation of expression of housekeeping genes in the range from 0.5 to 0.95 , and the level of standard deviation from the global mean for each set of genes grouped by the average expression is less than 0.3 , were considered to be of good quality. Samples of low quality were removed from the dataset.

\section{Standard Meta-Analysis}

The meta-analysis was performed using random-effects method [17], which takes into account the variance of heterogeneity between studies. The analysis was performed for each gene symbol and every tumor sample was compared with one of the normal pancreatic tissue samples selected randomly from the same dataset. False discovery rate is less than 0.05 , and the change of gene expression is $\geq$ 10 -fold were considered significant. The enzyme-coding up-regulated genes in PDAC compared to the normal pancreatic tissues were reported.

\section{Verification of the results in another dataset}

The Gene Expression Profiling Interactive Analysis (GEPIA) online database (http://gepia.cancer-pku.cn/index.html) is an interactive web server for analyzing RNA sequencing expression data of 9,736 tumors and 8,587 normal samples from the TCGA and the GTEx projects, using a standard processing pipeline [18]. It provides key interactive and customizable functions such as differential expression analysis between tumor and normal samples. Thus, to verify the results of this study, a boxplot was employed to visualize the expressions of up-regulated enzyme-coding genes identified in this study in pancreatic adenocarcinoma $(n=179)$ and normal pancreatic tissue datasets $(n=171)$ from TCGA and GTEx projects.

\section{RESULTS}

\section{Microarray Datasets}

A systematic search of the studies was carried out up to September 2019. Gene Expression Omnibus Datasets were searched with the term 'pancreatic ductal adenocarcinoma' and the search results were filtered by selecting organism as homo sapiens, study type as expression profiling by array and attribute name as tissue. As a result, 54 studies were found in GEO Database. It was carefully examined whether these studies met the inclusion criteria of this study. A total of 24 PDAC and 24 normal pancreatic tissue samples from five submissions (GSE46234, GSE19280, GSE43795, GSE41368, and GSE71989) were decided to be eligible for the meta-analysis (Table 1).

Table 1. Eligible public datasets used in the meta-analysis.

\begin{tabular}{|l|l|c|c|c|}
\hline $\begin{array}{l}\text { Public } \\
\text { Datasets }\end{array}$ & Platform & $\begin{array}{c}\text { PDAC } \\
\text { (n) }\end{array}$ & Healthy (n) & PMID \\
\hline GSE46234 & $\begin{array}{l}\text { HG-U133_Plus 2] Affymetrix Human } \\
\text { Genome U133 Plus 2.0 Array }\end{array}$ & 6 & 2 & - \\
\hline GSE19280 & $\begin{array}{l}\text { [HG-U133B] Affymetrix Human } \\
\text { Genome U133B Array }\end{array}$ & 4 & 3 & 23007696 \\
\hline GSE43795 & $\begin{array}{l}\text { Illumina HumanHT-12 V4.0 } \\
\text { expression beadchip }\end{array}$ & 6 & 5 & 24072181 \\
\hline GSE41368 & $\begin{array}{l}\text { [HuGene-1_0-st] Affymetrix Human } \\
\text { Gene 1.0 ST Array [transcript (gene) } \\
\text { version] }\end{array}$ & 6 & 6 & 24120476 \\
\hline GSE71989 & $\begin{array}{l}\text { [HG-U133_Plus_2] Affymetrix } \\
\text { Human Genome U133 Plus 2.0 } \\
\text { Array }\end{array}$ & 13 & 8 & 27363020 \\
\hline
\end{tabular}

Up-regulated Enzyme-coding Genes in PDAC

The random effect meta-analysis resulted in 22 differentially over-expressed genes in PDAC compared to the healthy pancreatic tissue samples (Table 2). The most significantly up-regulated gene in PDAC was POSTN (Periostin) with an approximately 45 -fold differential expression compared to the controls. The up-regulated enzyme-coding genes in PDAC were SULF1 (sulfatase 1, fold change=22.135) and KYNU (kynureninase, fold change=10.716).

Table 2: The differentially expressed genes with at least a 10-fold differential expression between pancreatic ductal adenocarcinoma and normal pancreatic tissues. *FDR: False discovery rate

\begin{tabular}{|c|c|c|c|c|}
\hline Gene Symbol & Gene Name & $\begin{array}{l}\text { Fold } \\
\text { Change } \\
\text { Combined }\end{array}$ & P-Value & $\mathrm{FDR}^{*}$ \\
\hline POSTN & periostin, osteoblast specific factor & 45.239 & 0 & 0 \\
\hline SULF1 & sulfatase 1 & 22.135 & 0 & 0 \\
\hline CEACAM6 & $\begin{array}{l}\text { carcinoembryonic antigen-related cell } \\
\text { adhesion molecule } 6 \text { (non-specific } \\
\text { cross reacting antigen) }\end{array}$ & 20.215 & 0 & 0 \\
\hline S100P & S100 calcium binding protein $\mathrm{P}$ & 20.178 & 0 & 0 \\
\hline CEACAM5 & $\begin{array}{l}\text { carcinoembryonic antigen-related cell } \\
\text { adhesion molecule } 5\end{array}$ & 16.492 & 0 & 0 \\
\hline IGHV3-52 & $\begin{array}{l}\text { immunoglobulin heavy variable 3-52 } \\
\text { (pseudogene) }\end{array}$ & 16.002 & $3.38 \mathrm{e}-06$ & 0.00139 \\
\hline IGKV2D-26 & $\begin{array}{l}\text { immunoglobulin kappa variable } \\
2 \mathrm{D}-26\end{array}$ & 15.32 & $4.47 \mathrm{e}-06$ & 0.001808 \\
\hline IGKV1D-33 & $\begin{array}{l}\text { immunoglobulin kappa variable } \\
1 \mathrm{D}-33\end{array}$ & 15.19 & $5.17 e-06$ & 0.002053 \\
\hline VCAN & versican & 13.152 & 0 & 0 \\
\hline SLC6A14 & $\begin{array}{l}\text { solute carrier family } 6 \text { (amino acid } \\
\text { transporter), member } 14\end{array}$ & 12.734 & 0 & 0 \\
\hline INHBA & inhibin beta $A$ & 12.479 & 0 & 0 \\
\hline COL1A2 & collagen, type I, alpha 2 & 12.331 & 0 & 0 \\
\hline LCN2 & lipocalin 2 & 12.008 & 0 & 0 \\
\hline IGKV1OR2-3 & $\begin{array}{l}\text { immunoglobulin kappa variable 1/ } \\
\text { OR2-3 (pseudogene) }\end{array}$ & 11.591 & $4.51 \mathrm{e}-07$ & 0.000189 \\
\hline FN1 & fibronectin 1 & 11.484 & $1.50 \mathrm{e}-13$ & $1.08 \mathrm{e}-10$ \\
\hline KYNU & kynureninase & 10.716 & 0 & 0 \\
\hline CXCL5 & chemokine (C-X-C motif) ligand 5 & 10.716 & $2.17 e-10$ & $1.09 \mathrm{e}-07$ \\
\hline CTHRC1 & $\begin{array}{l}\text { collagen triple helix repeat containing } \\
1\end{array}$ & 10.701 & $4.44 \mathrm{e}-16$ & $4.45 e-13$ \\
\hline ITGB6 & integrin beta 6 & 10.61 & 0 & 0 \\
\hline TFF1 & trefoil factor 1 & 10.307 & $1.87 \mathrm{e}-09$ & $8.97 \mathrm{e}-07$ \\
\hline COL3A1 & collagen, type III, alpha 1 & 10.249 & 0 & 0 \\
\hline SEMA3C & $\begin{array}{l}\text { sema domain, immunoglobulin } \\
\text { domain (Ig), short basic domain, } \\
\text { secreted, (semaphorin) 3C }\end{array}$ & 10.164 & 0 & 0 \\
\hline
\end{tabular}

\section{Validation based on TCGA and GTEx databases}

To validate the results of this study, the GEPIA database was used to compare the expression levels of the identified enzyme-coding up-regulated genes between PDAC and normal pancreatic tissues. As shown in Figure $1 \mathrm{~A}$ and $\mathrm{B}$, compared to normal pancreatic tissues, mRNA levels of kynureninase and sulfatase 1 were 7-fold and 3.5-fold higher in PDAC respectively $(p<0.05)$. These data were consistent with the results above from the GEO data sets in the context of a statistically significant increase in the expressions of the two enzyme-coding genes in PDAC. 


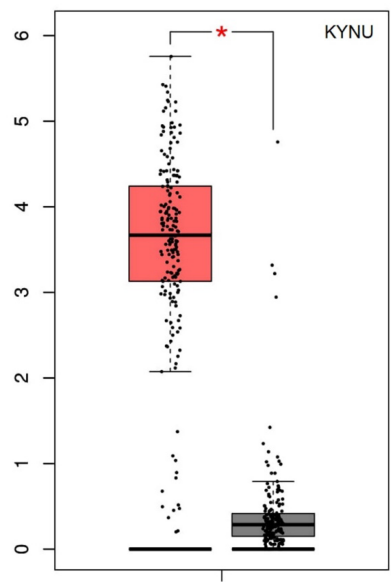

PAAD (num $(T)=179 ; \operatorname{num}(\mathrm{N})=171)$

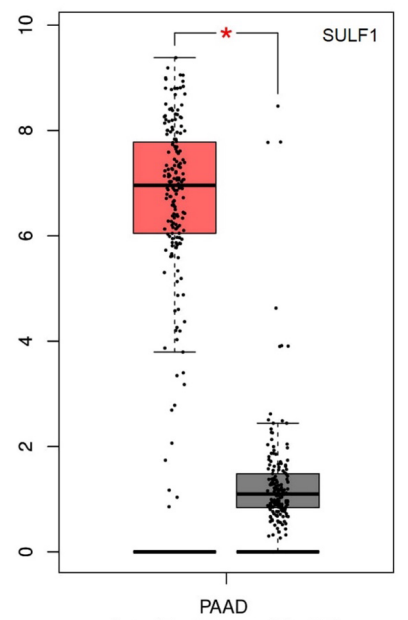

$\operatorname{num}(\mathrm{T})=179 ; \operatorname{num}(\mathrm{N})=171)$
Figure 1. Expression levels of KYNU (A) and SULF1 (B) in cancer and normal tissues. PAAD: Pancreatic Adenocarcinoma, T: Tumor, N: Normal; ${ }^{*} p<0.05$.

\section{DISCUSSION}

In the present study, an integrated transcriptomic meta-analysis was performed to suggest novel therapeutic targets and diagnostic biomarkers for PDAC. Based on the gene expression profiles of five GEO datasets, a total of 22 significantly overexpressed genes in PDAC were identified. Enzymes are preferred biomarkers for providing insight into the disease process by diagnosis, prognosis, and assessment of response therapy [19]. Besides, enzyme inhibitors constitute a significant portion of the druggable human proteome and the most important group of therapeutic agents that are in clinical use today [20,21]. Thus, this study focuses on the identified up-regulated enzyme-coding genes in PDAC to suggest more effective therapeutic targets and diagnostic biomarkers for PDAC. Since the number of samples that met the stringent inclusion criteria of this study is small, only genes with at least ten-fold differential expression between PDAC and normal pancreatic tissues were considered as significant to increase reliability. Among the up-regulated genes identified in PDAC, two genes were found to encode enzymes. One of them was SULF1 (Sulfatase 1), which encodes an extracellular heparan sulfate endosulfatase that removes 6-O-sulfate groups from internal glucosamine residues in highly sulfated subdomains of heparin/HSPGs. The first study investigating the molecular function of SULF1 in pancreatic cancer was conducted in 2005 and reported a 22.5-fold increase in the mRNA level of SULF1 in pancreatic cancer compared to normal controls [22]. Later, two distinct studies showed that SULF1 protein level is significantly higher in pancreatic cancer tissues than in cancer-adjacent normal pancreatic tissues [23, 24]. In this study, a 22.31-fold increase in the mRNA level of SULF1 was detected in PDAC compared to normal pancreatic tissues, consistent with the results from TCGA and GTEx data, and previous reports. Overall findings suggest that sulfatase may have the potential to be an effective diagnostic biomarker for PDAC, which merits further investigation. However, only two studies have evaluated whether SULF1 inhibition has the potential to be an effective therapeutic strategy in pancreatic cancer. It has been reported that stable SULF1 expression resulted in reduced both anchorage-dependent and -independent cell growth; however, decreased FGF-2 mediated cell growth and invasion in SULF-1 negative Panc-1 pancreatic cancer cell line [22]. In 2007, Nawroth et al. reported that the expression of human extracellular sulfatases SULF1 and SULF2 enhances Wnt signaling in pancreatic cancer cells and contributes to the growth and tumorigenicity of these cells [25]. Thus, these divergent results above indicate a poor understanding of the complex molecular mechanism of SULF-1 in the pathogenesis of pancreatic cancer and underline the need for further studies in this field.

In the present study, the second significantly up-regulated enzyme-coding gene in PDAC was KYNU. It's product, kynureninase or L-kynurenine hydrolase is involved in the biosynthesis of NAD cofactors from tryptophan through the kynurenine pathway [26]. KYNU expression has been demonstrated to be up regulated in cases with pediatric acute lymphoblastic leukemia [27] and lung adenocarcinoma [28] before. The results of these studies also suggested that the high expression of KYNU correlates with poor prognosis in patients. Moreover, it has been reported that inhibition of KYNU may represent a novel therapeutic approach for the treatment of glioma [29]. However, there are also studies that have reported a decrease in KYNU expression in highly aggressive osteosarcoma cell lines [30] and a negative association between KYNU expression and tumor grade in breast cancer [31]. The altered KYNU expression and thereby its molecular function may be associated with metabolic reprogramming in cancer development which could be easily affected by the specific metabolic demands of different cancer types. Since high expression of KYNU may give rise to higher NAD+ levels, it may also provide a selective advantage to cancer cells by increasing glycolysis via glyceraldehyde 3-phosphate dehydrogenase (GAPDH) and lactate dehydrogenase $(\mathrm{LDH})$ that require NAD as a co-enzyme, and by fueling cancer cells [31]. However, the role of KYNU in pancreatic cancer and cancer metabolism is not yet known. Further studies addressing these issues may reveal therapeutic, diagnostic or prognostic values of altered KYNU expression in pancreatic cancer and its importance in pancreatic cancer metabolism.

\section{REFERENCES}

1. Siegel RL, Miller KD, Jemal A. Cancer statistics, 2018 CA: a cancer journal for clinicians. 2018;68(1):7-30.

2. He X, Li Y, Su T, Lai S, Wu W, Chen L, et al. The impact of a history of cancer on pancreatic ductal adenocarcinoma survival. United European Gastroenterol J 2018;6(6):888-94.

3. Saad AM, Turk T, Al-Husseini MJ, Abdel-Rahman O. Trends in pancreatic adenocarcinoma incidence and mortality in the United States in the last four decades; a SEER-based study. BMC cancer 2018;18(1):688.

4. Weledji EP, Enoworock G, Mokake M, Sinju M. How Grim is Pancreatic Cancer? Oncol Rev 2016;10(1):294-.

5. Maitra A, Hruban RH. Pancreatic cancer. Annu Rev Pathol 2008;3:157-88.

6. Azar I, Virk G, Esfandiarifard S, Wazir A, Mehdi S. Treatment and survival rates of stage IV pancreatic cancer at VA hospitals: a nation-wide study. J Gastrointest Oncol 2019;10(4):703-11.

7. La Torre M, Nigri G, Lo Conte A, Mazzuca F, Tierno SM, Salaj A, et al. Is a preoperative assessment of the early recurrence of pancreatic cancer possible after complete surgical resection? Gut Liver 2014;8(1):102-8.

8. La Torre M, Nigri G, Cavallini M, Mercantini P, Ziparo V, Ramacciato G. The glasgow prognostic score as a predictor of survival in patients with potentially resectable pancreatic adenocarcinoma. Ann Surg Oncol 2012;19(9):2917-23.

9. Gillen S, Schuster T, Meyer Zum Büschenfelde C, Friess H, Kleeff J. Preoperative/neoadjuvant therapy in pancreatic cancer: a systematic review and meta-analysis of response and resection percentages. PLoS Med 2010;7(4):e1000267-e.

10. Zhao L, Zhao H, Yan H. Gene expression profiling of 1200 pancreatic ductal adenocarcinoma reveals novel subtypes. BMC cancer 2018;18(1):603.

11. Zheng B, Peng J, Mollayup A, Bakri A, Guo L, Zheng J, et al. Construction of a prognostic prediction system for pancreatic ductal adenocarcinoma to investigate the key prognostic genes. Mol Med Rep 2018;17(1):216-24.

12. Goonesekere NC, Wang X, Ludwig L, Guda C. A meta analysis of pancreatic microarray datasets yields new targets as cancer genes and biomarkers. PloS One 2014;9(4):e93046.

13. Goonesekere NCW, Andersen W, Smith A, Wang X. Identification of genes highly downregulated in pancreatic cancer through a meta-analysis of microarray datasets: implications for discovery of novel tumor-suppressor genes and therapeutic targets. J Cancer Res Clin Oncol 2018;144(2):309-20.

14. Haider S, Wang J, Nagano A, Desai A, Arumugam P, Dumartin L, et al. A multi-gene signature predicts outcome in patients with pancreatic ductal adenocarcinoma. Genome Med 2014;6(12):105.

15. Irigoyen A, Jimenez-Luna $\mathrm{C}$, Benavides $\mathrm{M}$, Caba $\mathrm{O}$, Gallego J, Ortuno FM, et al. Integrative multi-platform meta-analysis of gene expression profiles in pancreatic ductal adenocarcinoma patients for identifying novel diagnostic biomarkers. PloS One 2018;13(4):e0194844.

16. Sharov AA, Schlessinger D, Ko MSH. ExAtlas: An interactive online tool for meta-analysis of gene expression data. J Bioinform Comput Biol 2015;13(06):1550019.

17. DerSimonian R, Laird N. Meta-analysis in clinical trials. Controlled Clin Trials 1986;7(3):177-88.

18. Tang Z, Li C, Kang B, Gao G, Li C, Zhang ZJNar. GEPIA: a web server for cancer and normal gene expression profiling and interactive analyses. Nucleic Acids Res 2017;45(W1):W98-W102.

19. Hemalatha T, UmaMaheswari T, Krithiga G, Sankaranarayanan P, Puvanakrishnan R. Enzymes in clinical medicine: An overview. Indian J Exp Biol 2013;51:777-88

20. Copeland RA, Harpel MR, Tummino PJ. Targeting enzyme inhibitors in drug discovery. Expert Opin Ther Targets 2007;11(7):967-78.

21. Imming P, Sinning C, Meyer A. Drugs, their targets and the nature and number 
XXVII. Balkan Clinical Laboratory Federation Meeting BCLF 2019

XXX. National Congress of the Turkish Biochemical Society TBS 2019

of drug targets. Nat Rev Drug Discov 2006;5(10):821-34.

22. Li J, Kleeff J, Abiatari I, Kayed H, Giese NA, Felix K, et al. Enhanced levels of Hsulf-1 interfere with heparin-binding growth factor signaling in pancreatic cancer. Mol Cancer 2005;4(1):14-

23. Nawroth R, van Zante A, Cervantes S, McManus M, Hebrok M, Rosen SD. Extracellular sulfatases, elements of the Wnt signaling pathway, positively regulate growth and tumorigenicity of human pancreatic cancer cells. PloS One 2007;2(4):e392-e.

24. Lyu Y, Cheng Y, Wang B, Chen L, Zhao S. Sulfatase 1 expression in pancreatic cancer and its correlation with clinicopathological features and postoperative prognosis. Cancer Biomark 2018;22(4):701-7.

25. Nawroth R, van Zante A, Cervantes S, McManus M, Hebrok M, Rosen SD. Extracellular sulfatases, elements of the Wnt signaling pathway, positively regulate growth and tumorigenicity of human pancreatic cancer cells. PloS One 2007;2(4):e392.

26. Shi H, Enriquez A, Rapadas M, Martin E, Wang R, Moreau J, et al. NAD Deficiency, Congenital Malformations, and Niacin Supplementation. N Engl J Med 2017;377(6):544-52.

27. Gao HY, Luo XG, Chen X, Wang JH. Identification of key genes affecting disease free survival time of pediatric acute lymphoblastic leukemia based on bioinformatic analysis. Blood Cells Mol Dis 2015;54(1):38-43.

28. Wang H, Lu D, Liu X, Jiang J, Feng S, Dong X, et al. Survival-related risk score of lung adenocarcinoma identified by weight gene co-expression network analysis. Oncol Lett 2019;18(5):4441-8.

29. Adams S, Teo C, McDonald KL, Zinger A, Bustamante S, Lim CK, et al. Involvement of the kynurenine pathway in human glioma pathophysiology. PloS One 2014;9(11):e112945-e.

30. Lauvrak SU, Munthe E, Kresse SH, Stratford EW, Namløs HM, Meza-Zepeda LA, et al. Functional characterisation of osteosarcoma cell lines and identification of mRNAs and miRNAs associated with aggressive cancer phenotypes. Br J Cancer 2013;109(8):2228-36.

31. Yaku K, Okabe K, Hikosaka K, Nakagawa T. NAD Metabolism in Cancer Therapeutics. Front Oncol 2018;8:622-. 
XXVII. Balkan Clinical Laboratory Federation Meeting BCLF 2019

XXX. National Congress of the Turkish Biochemical Society TBS 2019

Illuminating the path to ISO 15189 accreditation: a view from the Republic of North Macedonia

Katerina Tosheska-Trajkovska ${ }^{1}$, Svetlana Cekovska ${ }^{1}$, Jasna Bogdanska ${ }^{1}$, Danica Labudovic $^{1}$, Irena Kostovska ${ }^{1}$, Julijana Brezovska ${ }^{1}$, Natasa Toseska-Spasova ${ }^{2}$, Coskun Kerala ${ }^{3}$, Venko Filipche ${ }^{4}$, Sonja Topuzovska

${ }^{1}$ Institute of Medical and Experimental Biochemistry, Medical Faculty, Ss Cyril and Methodius University in Skopje

${ }^{2}$ Faculty of Dentistry, Ss Cyril and Methodius University in Skopje

${ }^{3}$ University Clinic of Neurology, Ss Cyril and Methodius University in Skopje

${ }^{4}$ Public Health University Clinic for Neurosurgery, Skopje

\section{Abstract:}

In the Republic of North Macedonia the work of the diagnostic medical laboratories is regulated by the Law of Health Care. There is an urgent need for better development of an evidence-based, scientific, and sustainable national strategy for the improvement of health laboratory service. Clear indicators of improvement have to be established. A key indicator should be the number of laboratories that have achieved and can maintain accreditation.

The Macedonian Society of Medical Biochemistry and Laboratory Medicine (MSMBLM) recommends that the quality system established meets the requirements of the International Standard for medical laboratories ('Medical laboratories: Requirements for quality and competence [EN ISO 15189:2012] The accreditation of Macedonian medical laboratories is not mandatory; the decision for accreditation is voluntary. So far, nine medical laboratories have been accredited according the MKS EN ISO 15189:2013. Four of them are public sector laboratories.

The small number of accredited laboratories could be the result of the shortage of financial resources, poor government attention to laboratory service, the shortage of qualified personnel and/or the lack of a national laboratory policy.

The experiences of laboratory professionals from accredited laboratories, who have a high level of knowledge, skills, and competence, are crucially important to the process of developing a competent laboratory service within the national health system.

Key words: Accreditation, Quality Management System, ISO 15189, medical laboratories, biochemistry

\section{ISO 15189 akreditasyonuna giden yolun aydınlatılması: Kuzey Makedonya} Cumhuriyeti’nden görüșler

\section{Özet}

Kuzey Makedonya Cumhuriyeti’nde tıbbi laboratuvarların çalışmaları Sağlık Yasası ile düzenlenmiştir. Tıbbi laboratuvar hizmetinin iyileștirilmesi için kanıta dayalı, bilimsel ve sürdürülebilir bir ulusal stratejinin geliştirilmesine acil ihtiyaç vardır. $\mathrm{Bu}$ konuda açık iyileştirme göstergeleri tanımlanmalıdır. Temel bir gösterge, akreditasyon alan ve sürdüren laboratuvarların sayısı olmalıdır.

Makedonya Tıbbi Biyokimya ve Laboratuvar Tıbbı Derneği (MSMBLM), kurulan kalite sisteminin, tıp laboratuvarları için Uluslararası Standardın gerekliliklerini karşılamasını önermektedir ("Tıbbi laboratuvarlar: Kalite ve yeterlilik için şartlar" "[EN ISO 15189: 2012]).

Kuzey Makedonya'da tıp laboratuvarlarının akreditasyonu zorunlu değildir; akreditasyon kararı isteğe bağlıdır. Bugüne kadar MKS EN ISO 15189: 2013 uyarınca dokuz adet tıbbi laboratuvar akredite edilmiştir. Bunlardan dördü kamu sektörü laboratuvarıdır.

Kuzey Makedonya Cumhuriyeti'nde az sayıdaki akredite edilmiş laboratuvar bulunmasının nedenleri, finansal kaynakların yetersizliği, hükümetin laboratuvar hizmetine duyarsız kalması, kalifiye personel sıkıntısı ve / veya ulusal laboratuvar politikasının olmayışının sonucu olabilir.

Yeterli düzeyde bilgi, beceri ve yetkinliğe sahip olan akredite edilmiş laboratuvarlardaki laboratuvar uzmanlarının deneyimleri, ulusal sağlık sistemi içinde uzman bir laboratuvar hizmeti geliştirme süreci için çok önemlidir.

Anahtar kelimeler: Akreditasyon, Kalite Yönetim Sistemi, ISO 15189, tıbbi laboratuvarlar, biyokimya

\section{INTRODUCTION}

Laboratory medicine is a fundamental part of the modern healthcare system, and plays an important role in public health [1]. It is a very complex multidisciplinary diagnostic specialty with several interacting subdisciplines such as clinical biochemistry, hematology, immunology and others [2]. It depends on good knowledge of fundamental and applied sciences and the use of different technologies. Laboratory investigations are involved in every discipline of clinical medicine. Medical laboratories should ensure optimal test accuracy and precision, provide high quality laboratory test results, deliver test results in a timely manner and provide expert consultation to healthcare professionals [3]. However, legislators, clinicians, and patients are often unclear on the role of laboratory medicine as a specialty.

\section{THE IMPLEMENTATION OF LABORATORY STANDARDS IN THE} REPUBLIC OF NORTH MACEDONIA

In the Republic of North Macedonia the work of the diagnostic medical laboratories is regulated by the Law of Health Care [4]. Specific requirements for the laboratory service regarding capacities, equipment, health personnel and diagnostic tests are defined in the Rule Book for the necessary space, equipment and personnel for founding, starting and performing healthcare procedures in a health care establishment [5]. This document is insufficient; there is an urgent need for better development of an evidence-based, scientific, and sustainable national strategy for the improvement of health laboratory service. Clear indicators of improvement must be established. A key indicator should be the number of laboratories that have achieved, and can maintain accreditation.

Accreditation is formal recognition that a body or person is competent to carry out specific tasks. Meeting the International Standard means the laboratory meets the technical competence requirements and the management requirements to consistently deliver technically valid results.

Audit of Management System can be conducted by non-technical personnel. It includes assessment of management activities, such as:

- purchasing of consumable materials

- management of calibration system;

- contracts / client interactions;

- document control and revision;

- training records.

Audit of Technical Competence must be conducted by someone familiar with test/methodology/performance of tests. The auditor assesses:

- sampling activities;

- preparation of reagents and/or samples;

- results / data analysis;

- performance of test.

\section{The role of scientific societies}

The Macedonian Society of Medical Biochemistry and Laboratory Medicine (MSMBLM) recommends that the quality system established meets the requirements of the EN ISO 15189:2012 "Medical laboratories: Requirements for quality and competence" (EN ISO 15189:2012) [6], which has been accepted as the fundamental standard for the accreditation of medical laboratories in European countries. EN ISO 15189 was developed as a baseline standard for the Quality Management System (QMS) in medical laboratories and is recognized as the connecting standard for all disciplines in laboratory medicine.

MSMBLM is a professional society of specialists in medical biochemistry. It is responsible for the translation of international guidelines into national guidelines. These guidelines have to be in agreement with the standard EN ISO 15189. For this purpose, cooperation between MSMBLM and the National Accreditation Body, Institute for Accreditation of the Republic of North Macedonia (IARM) [7] is essential. IARM, established in 2003, is a non-profit institution with a duty/ task to act in the public interest. It is a subject to peer evaluation. In 2008 IARM has become a member of the International Laboratory Accreditation Cooperation (ILAC), which is an umbrella organization for regional accreditation cooperation. The acceptance of accredited laboratory data is facilitated through mutual recognition arrangements among accreditation bodies.

In Europe this is regulated by the European cooperation for Accreditation (EA) [8]. ISO 15189 is covered by the Health Care Committee (HCC) of EA, where, apart from almost all European Accreditation Bodies, European Federation of Clinical Chemistry and Laboratory Medicine and Medtech are represented [9$12]$.

The Law of accreditation was endorsed in 2009 (Official Journal of R.M. No. 120/2009). In 2013, the Standardization Institute of the Republic of North Macedonia accepted the standard as the Macedonian norm for quality assessment of medical laboratories (MKS EN ISO 15189:2013).

The accreditation of medical laboratories in Republic of North Macedonia is not mandatory; the decision for accreditation is voluntary. Accreditation is accessible to every client submitting an accreditation application to the National Accreditation Body. Assessment is performed every 4 years and surveillance is carried out annually. Flexible scope is not yet started but it is offered to accredited 
laboratories that have already demonstrated that they have a verification/ validation procedure that justifies the trust that comes with a flexible scope [13]. In 2013, the first medical biochemistry laboratory was accredited in our country. So far, nine medical laboratories of 240 registered laboratories have been accredited according to the MKS EN ISO 15189:2013. Four of them are public sector laboratories. Research Center for Genetic Engineering and Biotechnology "Georgi D. Efremov", which is a research unit of the Macedonian Academy of Sciences and Arts, and Diagnostic laboratories of the Institute of Pathology, Faculty of Medicine in Skopje are accredited according to MKS EN ISO 17025:2006.

The small number of accredited laboratories could be a result of the limited budget, especially for public medical laboratories, poor government attention to laboratory service, logistic and/or the lack of a national laboratory policy.

As the quality of laboratory service is a fundamental component of the healthcare system, the successful implementation of the accreditation process will bring a measurable quality improvement in laboratory service and, consequently, in the healthcare system [14-16]. Therefore, the Ministry of Health, professional associations, and other stakeholders should work together to make accreditation of medical laboratories a high priority and should undertake coordinated activities to integrate accreditation programs into national health policy and planning. Training by the Laboratory Quality Management system (LQMS) is a priority, with ISO 15189 accreditation as the ultimate goal [17]

\section{Experience of implementing MK EN ISO 15189:2012 for accreditation of a} university medical laboratory

Accreditation of a university laboratory is a difficult task, since teachers and teaching assistants have to coordinate different tasks, which makes the number of people involved in the process of accreditation quite variable. Implementation of a quality system on ISO 15189 and accreditation are completely achievable in this setting, in spite of the fact that this is a very demanding process. The experience of implementing a quality system on ISO 15189, and the accreditation of some tests for a university laboratory, is presented in the example of the Biochemical Analyses Laboratory (BAL), within the Institute of Medical and Experimental Biochemistry, the first public biochemical laboratory accredited according to MK EN ISO 15189:2013 in the Republic of North Macedonia.

\section{Application for accreditation}

Application should contain:

\section{General data about the organization}

1.1. Name and description of activities of the laboratory according to standard classification;

1.2. Legal identity of the organization;

1.3. Organizational structure of the laboratory and its position in the organization (with organizational scheme);

1.4. The names and position of key personnel with technical responsibility for testing and responsibility for quality assurance (head of laboratory, quality manager);

1.5. Personnel (technical staff);

1.6. Premises (locations where the tests are performed for the applied scope of accreditation);

1.7. When was the quality system according to standard $M K C$ EN ISO 15189: 2013 implemented?

\section{Scope of accreditation}

Scope of accreditation identifies precisely the field of testing (classification according to IARM Regulation R 15). Scope of accreditation includes a listing of test methods, range of measurement, and biological material on which the testing is done.

The laboratory can claim accreditation only for the tests listed on the scope of accreditation.

\section{Short description of the equipment}

There has to be an appropriate equipment for realization of the respective laboratory tests. Equipment should be routinely calibrated and well-maintained.

\section{The accreditation will be valid if:}

1. Team members should have prior knowledge of the document

Document should be delivered to all staff members. They should be familiar with the technical and management requirements of the standard.

\section{The accreditation team should be trained, competent and objective}

The team is not going to be effective if it is composed solely of managers and leaders. Mutual trust and respect has to exist among the members of the team. The team has to promote safety and openness. If people feel that they are psychologically safe, they will be more open to share ideas, to say their opinion or to suggest new approaches. Dominance in the team should be avoided, but diversity is accepted, because diverse teams are much more productive. If there are opposite opinions in the team, people can overcome their way of thinking. Every team member should be trained and competent to perform different tasks in the laboratory. Team members should be people who are at the front line, people who are closest to the process, people who are experts in each step of the testing process, people who perform some tasks every day and know to perform them in the best possible way. Not all team members need to be involved in all phases of the work, but they should be included when decisions related to their area are being made.

\section{The laboratory should improve its performance continuously}

Accreditation requires that a lab has a quality management system that focuses on continuous improvement. Improvement should not be done to people, but it should be created with people. When people come to work every day, they should think not only to do their work but to improve it. Continuous improvement is essential for success.

Improvement should be a part of the culture of the organization and a natural part of how people perform their jobs.

\section{Key steps in the process of accreditation}

\section{Development of a Quality Manual}

The Quality manual is the key document describing the overall Quality Management System. It should provide an understanding of the laboratory management and organizational structure; it describes roles and responsibilities of Quality Manager and Laboratory Director; it gives framework for design and implementation of the quality management system in the lab.

All staff members have to be familiar with the content and application of the quality manual and the referenced documents.

\section{Development of process control}

In terms of process control, preparation of standard operational procedures (SOPs) and working instructions are necessary in the initial phase.

SOPs are documents with step-by-step written instructions for each procedure performed in the laboratory. The purpose of these documents is to make sure that all procedures are performed consistently (correctly and always in the same manner) by everyone in the laboratory. A well-known rule in the process of SOP creation is 'write what you are doing and do what you're writing'.

\section{Development of a management system for documented information}

Every laboratory should have a control over the documented information. All relevant documents, records and policies have to be managed under controlled conditions and have to be reviewed and approved by authorized personnel prior to use. A written system of document preparation with declared responsibility for the documents. Structured and organized control of documents allows the lab to function more efficiently. Managing and controlling of documents is an overwhelming process, but the time and effort put into improving the laboratory performance are well worth it.

\section{Internal quality control (IQC)}

IQC is a segment of the quality management system used to ensure the accuracy of the results. It involves the in-house procedures to ensure day-to-day consistency of an analytical (examination) process. All personnel should be trained for 
XXVII. Balkan Clinical Laboratory Federation Meeting BCLF 2019

XXX. National Congress of the Turkish Biochemical Society TBS 2019

implementation of IQC. If QC results are not acceptable, laboratory should not report patient results.

\section{External Quality Assessment (EQA)}

EQASs are designed for the objective assessment of the laboratory's performance using an external agency or facility. All laboratories should be enrolled in EQAS program, a process in which a laboratory receives an unknown sample to test and report the findings back to the EQAS provider. EQA should not be punitive. It should be used as a tool for improvement of laboratory performance. EQA programs will assist laboratories in improving analytical quality, inter-laboratory agreement, identify potential equipment or reagent failures, and identify any training deficiencies. Some EQA programs are voluntary while others are obligatory, either required by an accrediting body or by law. For laboratories that are accredited, or that plan to seek accreditation, EQA participation is usually required.

\section{Sample storage}

Every laboratory should have written policies for types of samples that can be stored, correct sample labeling, location of stored samples, retention time, ambiental conditions for storage, maintenance and disposal of samples.

The laboratory should have standard procedures for safety issues like disposal of all laboratory waste and patient samples in accordance with national regulations for disposal of medical waste.

\section{Reporting of results}

Results should be reliable and accurate and reported in a timely manner.

Every laboratory should have a procedure to ensure correctness of transcription of laboratory results.

Each laboratory should have written procedure for reporting of critical results Comments on sample suitability with respect to acceptance/rejection criteria or sample quality that might compromise test results should be included.

The content of the report should be according to the requirement of the standard EN ISO:15189:20112 (section 5.8.3).

\section{Laboratory Information System (LIS)}

An integrated Laboratory Information system (LIS) is crucial for the efficient management of work processes, quality control and financial planning. It is hard to imagine a modern diagnostic laboratory functioning without the use of a LIS. A good information management system will ensure that all data, including the final report is well managed; LIS should ensure the accessibility, accuracy, timeliness and security of data, as well as confidentiality and privacy of patient information.

\section{Critical elements for improvement of the laboratory quality management} system

In the 10-year-period as an accredited laboratory, we have identified critical elements for improvement of the laboratory quality management system.

Communication

Communication is essential for quality. Each team member should be informed what was done in the past, what is in progress and which are future plans. Dissemination of information within the laboratory and between the laboratory and its customers is crucial for effective fulfillment of requirements and needs of customers.

Cause and effect diagram (Fishbone diagram)

One of the basic tools of quality improvement is the Fishbone diagram which identifies the possible causes of errors, called failure modes, and their effects. Failure modes effect analysis (FMEA) allows identification of the effects (criticality, severity and probability of occurrence).

Root Cause analysis is a system of problem solving methods aimed at identifying the root cause of problems or incidents. By directing corrective measures at root causes, it is hoped that the likelihood of problem recurrence will be minimized. Participation in EQAS

EQA is one of the critical elements for improvement of the laboratory quality management system because it represents a measure of laboratory performance. A laboratory must develop a plan to demonstrate coverage of the test methods on its scope of accreditation over a 4-year-period. It is mandatory to demonstrate successful participation in EQAS. Acceptance criteria is +/- 2SD. Corrective action has to be taken for any outlying results.

As accredited laboratory, BAL has an obligation to fulfill two documents: plan for participation in EQAS/PT (document OB 05-18-2) and review of participation (document $\mathrm{OB}$ 05-18) and to present them to the lead assessor and technical assessor on annual basis during the on-site assessment of the laboratory.

Some benefits of EQAS participation include:

- Discovering of sources of error,

- Systematic errors,

- Demonstration of effectiveness of changes,

- Common understanding of method differences,

- Discovery of method sensitivities,

- Comparison of laboratory's internal methods against standard methods,

- It can be a source of method validation for new measurement techniques, methods, etc.

- EQAS also can lead to method/standard improvement.

Corrective and Preventive actions

Accreditation requires that a lab have a quality management system that focuses on continuous improvement. A critical part of that management system is identifying when the system doesn't conform to the requirements and taking action to correct the problem and eliminate the root cause to avoid recurrence of the problem.

Implemented corrective and preventive actions need to be periodically monitored to ensure that they were effective and resolve the problem or potential problem.

\section{Overall benefits of accreditation}

- Increased confidence in data;

- Reduced uncertainties associated with decisions;

- Issues with methods, personnel, and equipment are identified and resolved more quickly;

- Customer satisfaction is improved;

- Business opportunities may increase.

\section{Conclusions and future directions}

The globalization of markets and migration of health professionals requires improving the laboratory diagnostic process. A quality laboratory system is the foundation of a strong national health system [18-21]. Laboratory workforce, infrastructure, and quality management system are vital for the delivery of quality laboratory services. Coordination with the Ministries of Education and Health is essential for maintaining standards of education and levels of knowledge. The competency of laboratory professionals has to be maintained through mandatory participation in continuous medical education (CME). Appropriate laboratory facilities, infrastructure, and equipment for each laboratory tier level are essential to enable safely and efficient performance. Strong programs supporting quality assurance, quality control, and quality improvement should exist. They are fundamental for the establishment, maintenance and improvement of laboratory quality systems. SOPs must be well-written, understood, and implemented; laboratory personnel should routinely perform IQCs; and laboratories must be required to participate in EQA or proficiency testing $(\mathrm{PT})$ programmes.

For Government, Ministry of Health, professional association(s) and stakeholders, accreditation of medical laboratories according to IS 15189:2012 should be a high priority. They should act together and undertake coordinated efforts to integrate accreditation programs into national health policy, planning, and health development programmes.

\section{References}

[1] Lippi G, Plebani M, Graber ML. Building a bridge to safe diagnosis in healthcare. The role of a clinical laboratory. Clin Chem Lab Med 2016; 54 (1):13

[2] Alonso-Cerezo MC, Martin JS, Garcia Montes MA, de la Iglesia VM. Appropriate utilization of clinical laboratory tests. Clin Chem Lab Med 2009; 47 (2) 1461-5.

[3] Oosterhuis WP, Zerah S. Laboratory medicine in the European Union. Clin Chem Lab Med 2015;53:5-14.

[4] The Law on health care, Official Gazette of the Republic of Macedonia No $10 / 2013$, art. 71 .

[5] Rule Book for the necessary space, equipment and personnel for founding, starting and performing healthcare procedures in a health care establishment, Official Gazette of the Republic of Macedonia No 91/2013, arts15-23.

[6] International Organization for Standardization, 2012. ISO 15189:2012: Medical laboratories: particular requirements for quality and competence.

[7] Institute for accreditation of the Republic of North Macedonia, http://iarm. gov.mk/ (Last accessed: 20 February 2019)

[8] Mehay H, Boursier G, Vaubourdolle M. European Network for Accreditation 
XXVII. Balkan Clinical Laboratory Federation Meeting BCLF 2019

XXX. National Congress of the Turkish Biochemical Society TBS 2019

of medical labs: update on the EFLM and EA surveys. 21st Joint EFLM-IFCC EuroMedLab congress, 24th 2015 June.

[9] Huisman W. European communities confederation of clinical chemistry working group on accreditation: past, present and future. Clin Chim Acta 2001;309:111-4.

[10] Huisman W, Horvath AR, Burnett D, Blaton V, Czikkely R, et al. Accreditation of medical laboratories in the European Union. Clin Chem Lab Med 2007;45:268-75.

[11] Blaton V. Accreditation and postgraduate training in European countries: an FESCC survey. Federation of European Societies of Clinical Chemistry. Clin Chim Acta 2001;309:115-20.

[12] Huisman W. European medical laboratory accreditation. Present situation and steps to harmonisation. Clin Chem Lab Med 2012;50:1147-52.

[13] Thelen MH, Vanstapel FJ, Kroupis C, Vukasovic I, Boursier G, Barrett E, et al. Flexible scope for ISO 15189 accreditation: a guidance prepared by the European Federation of Clinical Chemistry and Laboratory Medicine (EFLM) Working Group Accreditation and ISO/CEN standards (WG-A/ISO). Clin Chem Lab Med 2015;53:1173-80.

[14] Zima T. Accreditation of medical laboratories-system, process, benefits for labs. J Med Biochem 2017; 36:1-6.

[15] Zima T. Accreditation in clinical laboratories. Biochem Med 2010; 20/2: $215-20$.

[16] Dybkaer R. Quality Assurance, Accreditation, and Certification: Needs and Possibilities. Clin Chem 1994; 40/7: 1416-20.

[17] Boursier G, Vukasovic I, Mesko Brguljan P, Lohmander M, Ghita I, et al. Accreditation process in European countries - an EFLM survey. Clin Chem Lab Med 2016; 54(4): 545-51.

[18] Sayed S, Cherniak W, Lawler M, Tan SY, El Sadr W, et al. Improving pathology and laboratory medicine in low-income and middle-income countries: roadmap to solutions. Lancet 2018; 391(10133):1939-52.

[19] World Health Organization, Development of National Health Laboratory Policy and Plan http://apps.searo.who.int/PDS DOCS/B4725.pdf (Last accessed: 20 June 2019)

[20] World Health Organization, Laboratory Quality Standards and their Implementation Available from:

http://apps.who.int/medicinedocs/documents/s22409en/s22409en.pdf?ua=a (Last accessed: 17 September 2019)

[21] World Health Organization, Regional Office for Europe, 'Better Labs for Better Health - strengthening laboratory systems in the WHO European Region. Progress report 2016-2017 (2018) Available from: www.euro.who.int/en/healthtopics/Health-systems/laboratory services/publications/better-labs-for-betterhealth-strengthening-laboratory-systems-in-the-who-european-region-2018 (Last accessed: 18 July 2019) 


\section{Induction of APAF-1 and TRAIL by bilberry tea in HCT-116 colon cancer cell line \\ [Yabanmersini çayı ile HCT-116 kolon kanseri hücre hattında APAF-1 ve TRAIL'in uyarılması]}

Burak Durmaz ${ }^{1}$, Latife Merve Oktay ${ }^{2}$, Hikmet Memmedov', Nur Selvi Günel ${ }^{2}$, Hatice Kalkan Yıldırım³ ${ }^{3}$ Eser Yıldırım Sözmen ${ }^{1}$

${ }^{1}$ Ege University Faculty of Medicine, Department of Medical Biochemistry, İzmir ${ }^{2}$ Ege University, Faculty of Medicine, Department of Medical Biology, İzmir

${ }^{3}$ Ege University Faculty of Engineering, Department of Food Engineering, İzmir

\section{ABSTRACT}

Objectives: In this study, we aimed to determine the effect of bilberry tea samples on the markers of the intrinsic and extrinsic pathways of apoptosis in the HCT116 colon cancer cell line.

Materials and Methods: Bilberry tea in different infusions and boiling periods (1 $\mathrm{min}, 3 \mathrm{~min}, 5 \mathrm{~min}, 10 \mathrm{~min}$ ) were prepared and phenolic levels were determined by LC MS / MS technique. The highest phenolic content was determined in tea samples of dried shredded fruit for 5 min boiling, so this product was chosen for in vitro study. Cytotoxicity and viability tests were performed by adding WST-8 solution. Intrinsic and extrinsic pathways of apoptosis were assessed by determining the TNF-related apoptosis-inducing ligand (TRAIL), Apoptotic Protease Activating Factor-1 (APAF-1), Cytochrome-c, Caspase -3,-8,-9 levels in HCT-116 colon cancer cell line.

Results: Cytotoxicity studies in cell culture were conducted using 50-10 $\mu \mathrm{g} / \mathrm{ml}$ of bilberry tea samples which was prepared at a concentration of $5 \mathrm{~g} / 10 \mathrm{ml}$. The levels of Caspase 3, APAF-1, TRAIL and Cytochrome-c were significantly higher in bilberry added cell culture than the control cells. Other markers (caspase - $8,-9$ levels) did not show any significant change compared to control cells.

Conclusions: It is concluded that bilberries induced TRAIL, APAF-1, Caspase-3, Cytochrome-c and consequently induced both intrinsic and extrinsic pathways of apoptosis.

\section{Keywords: APAF-1, TRAIL, bilberry, HCT-116, colon cancer}

\section{ÖZET}

Amaç: Bu çalışmada, yaban mersini çayı örneklerinin HCT-116 kolon kanseri hücresindeki apoptozun iç ve dış yolaklarında apoptoz belirteçleri üzerindeki etkisinin belirlenmesi amaçlandı.

Malzeme ve yöntemler: Yabanmersini çayı farklı infüzyonlarda ve kaynama sürelerinde ( 1 dak, 3 dak, 5 dak, 10 dak) hazırlandı ve fenolik seviyeler LC MS / MS tekniği ile belirlendi. En yüksek fenolik içerik, 5 dakika kaynama için kuru paralanmış meyvelerin çay örneklerinde belirlendi, bu yüzden bu ürün in vitro çalışma için seçildi. Sitotoksisite ve canlılık testleri WST-8 çözeltisi ilave edilerek yapıldı. Apoptozun iç ve dış yolakları, HCT-116 kolon kanseri hücre hattında TNF-related apoptosis-inducing ligand (TRAIL), Apoptotic Protease Activating Factor-1 (APAF-1), Sitokrom-c, Kaspaz -3, -8, -9 seviyelerinin belirlenmesiyle değerlendirildi.

Bulgular: Hücre kültüründe sitotoksisite çalışmaları, $5 \mathrm{~g} / 10 \mathrm{ml}$ konsantrasyon da hazırlanan 50-10 ug / ml yabanmersini çay numunesi kullanılarak gerçekleştirildi. Yabanmersini çay örnekleri eklenmiş hücre kültüründe kaspaz-3, APAF-1, TRAIL ve Sitokrom-c seviyeleri kontrol hücrelerine göre anlamlı derecede yüksek bulundu. Diğer belirteçler (kaspaz -8, -9 seviyeleri) kontrol hücrelerine kıyasla anlamlı bir değişiklik göstermedi.

Sonuç: Yabanmersininin TRAIL, APAF-1, kaspaz-3, sitokrom-c'yi indüklediği ve sonuç olarak apoptozun hem iç hem de dış yolaklarını indüklediği sonucuna varılmıştır.

Anahtar Sözcükler: APAF-1, TRAIL, yaban mersini, HCT-116, kolon kanseri

\section{Introduction}

Cancer; is a pathological condition caused by disruption of the balance between cell proliferation and cell death due to excessive cell proliferation or decreased apoptosis. It has been reported that suppressed or decreased apoptosis plays an important role in cancer development (1). According to data from the American Cancer Society, $12.5 \%$ of annual deaths worldwide are caused by cancer and approximately 8,8 million people die annually from cancer (2). The probability of lifetime cancer diagnosis is $39.7 \%$ for men and $37.6 \%$ for women. The most common cancers to be diagnosed in men are prostate, lung and colorectal cancers, which constitute $42 \%$ of all cases. In women, the most common cancers to be diagnosed are breast, lung and colorectal cancers, representing half of all cases (3).

Chemotherapy is one of the commonly used methods for cancer treatment. Two target mechanisms come into prominence in preventing the proliferation of cancer cells with chemotherapeutic drugs. These are inhibition of cell growth or activation of apoptosis. Stopping the cell cycle is an effective strategy in eliminating cancer cells. Apoptosis is regulated by the factors in intrinsic and extrinsic signaling pathways (4).

In recent years, the use of natural sources as anticancer agents has become a popular research area, because of the resistance to anticancer drugs and cytotoxic effect of these anticancer agents against normal cells in long-term usage (5). Plants have been used for centuries to overcome human and animal diseases. Today, approximately $50 \%$ of the modern drugs used to suppress the proliferation of cancer cells in the clinic are obtained from natural products (6). According to the estimates of the World Health Organization, approximately $80 \%$ of the people living in developed countries use traditional treatment to solve their primary health problems (5). Therefore, natural products are considered as potential pharmaceutical raw materials (1).

The aim of this study was to investigate the effect of bilberry tea sample on the molecules of apoptosis pathways in HCT-116 colon cancer cell line.

\section{Material and method}

Materials

McCoy's 5A, Fetal Bovine Serum, Penicilin/Streptomycin, L-Glutamin were purchased from Capricorn Scientific (Ebsdorfergrud, Germany). All of the phenolic compound standards, Dimethyl sulphoxide (DMSO) and Trypan Blue were purchased from Sigma (USA). WST-8 Cell Proliferation Assay Kit were purchased from Cayman Chemical (Michigan, USA). Human (TRAIL) and Caspase (-3,-8-9 ELISA Kits were purchased from Genosis (USA). Human Apoptotic Protease Activating Factor-1 (APAF-1) ELISA Kit was purchased from Biosens (USA).

\section{Bilberry Tea Preparation}

Bilberries were harvested from Menderes region near to Izmir. Hand harvested fruits were destemmed and calibrated on the basis of equal sizes. Samples were stored at $-20^{\circ} \mathrm{C}$ before analyses. As study material, different forms of bilberry fruit and leaves were used: dried leaves, dried fruit, dried shredded raw fruit, frozen raw fruit, seedless fruit and fruit seeds. Dried leaves (DL) were separated manually from aerial parts in laboratory and dried at $60^{\circ} \mathrm{C}$ for 15 min in tray dryer. Processed leaves were finely ground with small home blender (Joyce home electrical accessory Co. Ltd). Dried fruits (DF) were obtained by similar drying processing procedure with different conditions: $40^{\circ} \mathrm{C}$ for $60 \mathrm{~min}$. Dried shredded fruits (DSF) were processed in similar way to dried fruit and finely ground with small home blender (Joyce home electrical accessory Co. Ltd). Frozen fruits (FF) were obtained by freezing the fruits at $-15^{\circ} \mathrm{C}$ for $24 \mathrm{~h}$. Seedless fruits (SF) were prepared by manual separation of seeds in laboratory. Fruit seeds (FS) were also obtained and used.

Tea processing was done by using two types of extraction procedures: infusion and boiling. Infusion was done by keeping the obtained products in previously boiled water $100^{\circ} \mathrm{C} / 5 \mathrm{~min}$ for different times $(1 \mathrm{~min}, 3 \mathrm{~min}, 5 \mathrm{~min}, 10 \mathrm{~min})$. Boiling was carried out by keeping the obtained products in continuously boiling water $\left(100^{\circ} \mathrm{C}\right)$ for different times $(1 \mathrm{~min}, 3 \mathrm{~min}, 5 \mathrm{~min}, 10 \mathrm{~min})$.

\section{Determination of the amount of phenolic compounds by LC MS / MS Analysis}

Quantitative analysis of the components was performed using the external standard method. The analysis were performed on Waters Xevo TQD system (Waters) containing automatic sample injection and UHPLC. Acquity UPLC BEH C18 $(50 \times 2.1 \mathrm{~mm}, 1.7 \mu \mathrm{m})$ column was used for the separation. The spectral range covered was from 190 to $360 \mathrm{~nm}$. Column temperature of $45{ }^{\circ} \mathrm{C}$ and injection volume of $5 \mu \mathrm{L}$ were selected. Based on the molecular spectrum of the standards, two wavelengths were used. The flow rate was $0.3 \mathrm{~mL} / \mathrm{min}$ and the UV scan was carried out in the range of 254-280 $\mathrm{nm}$. The optimum $\mathrm{pH}$ value for the separation efficiency was chosen between 2-3. The mobile phase was designated to be methanol $+0.1 \%$ formic acid $(\mathrm{FA})$ and water $+0.1 \%$ formic 
XXVII. Balkan Clinical Laboratory Federation Meeting BCLF 2019

XXX. National Congress of the Turkish Biochemical Society TBS 2019

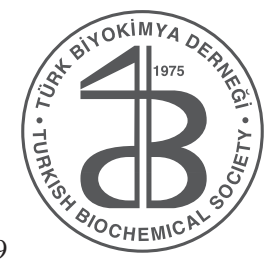

acid. A linear gradient defined was used for elution.

Cell culture

HCT-116 human colon cancer cell line was purchased from American Type Culture Collection (ATCC) and were multiplied in McCoy's 5A medium supplemented with $10 \%$ fetal calf serum (FBS), 100 unit/ml penisilin, and 100 $\mu \mathrm{g} / \mathrm{ml}$ streptomycine and incubated at $37^{\circ} \mathrm{C}$ in a humid environment containing $5 \% \mathrm{CO}_{2}$.

\section{Determination of Apoptosis in Cell Culture}

The highest phenolic content was determined in tea samples of DSF for $5 \mathrm{~min}$ boiling, so this product was chosen for in vitro study. After the HCT-116 colon cancer cells were plated in 6-well plates at $1 \mathrm{million} / \mathrm{mL}$, the tea sample was applied and the cells were collected following the incubation period of 48 hours, centrifuged for $20 \mathrm{~min}$ at 2000-3000 rpm. Later, they were centrifuged at 2000-3000 rpm for 20 minutes again making icing-deicing application three times. Human TRAIL, Human APAF-1) Cytochrome-C, Caspase-3, Caspase-8, Caspase- 9 were determined with commercially available ELISA kits.

\section{Results}

The main phenolic contents of tea samples are presented in Table 1 and Table 2.

Table 1: LC MS/MS results of phenolic compounds (ng/ml) of different samples with different brewing times

\begin{tabular}{|c|c|c|c|c|c|c|c|c|}
\hline Brewing & Caffeic acid & Kaempherol & Ferulic acid & Quercetin & Vanilic acid & Ellagic acid & Delphinin & Pelargonin \\
\hline \begin{tabular}{|l} 
Dry Leaf $1 \mathrm{~min}$ \\
\end{tabular} & $\begin{array}{r}11,80 \\
\end{array}$ & \begin{tabular}{|l|}
12,32 \\
\end{tabular} & 27,35 & \begin{tabular}{|l|l|}
5 & 141,48 \\
\end{tabular} & 397,54 & 25,13 & \begin{tabular}{|l|l|}
3 & 18,08 \\
\end{tabular} & $8 \quad 40,71$ \\
\hline Dry Leaf $3 \mathrm{~min}$ & 7,57 & 23,59 & 59,88 & 271,63 & 346,92 & 41,97 & 73,65 & \\
\hline Dry Leaf $5 \mathrm{~min}$ & 7,95 & 44,27 & 145,33 & 253,64 & 1079,18 & 31,85 & 56,88 & \\
\hline Dry Leaf $10 \mathrm{~min}$ & 6,52 & 20,76 & 41,06 & \begin{tabular}{c|c|}
165,03 \\
\end{tabular} & 225,82 & 30,11 & $\begin{array}{ll}45,88 \\
\end{array}$ & 13,38 \\
\hline Dry Fruit $1 \mathrm{~min}$ & 8,92 & 80,10 & 218,04 & 732,54 & 1475,20 & 82,49 & 152,25 & 185,34 \\
\hline Dry Fruit 3 min & 5,91 & 25,99 & 77,37 & 155,21 & 183,79 & 17,24 & 40,19 & 30,98 \\
\hline Dry Fruit 5 min & 6,75 & 63,11 & 261,18 & 742,14 & 581,75 & 68,17 & 166,12 & 237,17 \\
\hline Dry Fruit $10 \mathrm{~min}$ & 6,37 & 16,04 & 55,35 & 253,26 & 158,40 & 33,81 & 59,92 & 24,34 \\
\hline Dry shredded raw fruit $1 \mathrm{~min}$ & 5,65 & 527,84 & 344,13 & 7087,67 & 128,29 & 689,70 & 1551,26 & 176,98 \\
\hline Dry shredded raw fruit $3 \mathrm{~min}$ & 6,09 & 432,75 & 359,15 & 5222,89 & 286,45 & 511,49 & 1206,45 & 85,61 \\
\hline Dry shredded raw fruit 5 min & 7,01 & 482,17 & 457,65 & 6091,25 & & 567,81 & 1373,23 & 169,98 \\
\hline Dry shredded raw fruit $10 \mathrm{~min}$ & 5,81 & 430,24 & 267,54 & 5341,57 & & 501,16 & 1126,68 & 41,69 \\
\hline Frozen Raw Fruit $1 \mathrm{~min}$ & $\frac{6,031}{6,31}$ & $\begin{aligned} 450,23 \\
6,23 \\
\end{aligned}$ & $\begin{array}{c}20,3,45 \\
38,85 \\
\end{array}$ & $\begin{array}{ll}3.354,27 \\
135,27\end{array}$ & 284,45 & $\frac{01,16}{14,55}$ & 119,94 & $\begin{array}{l}25,7034 \\
\end{array}$ \\
\hline Frozen Raw Fruit $3 \mathrm{~min}$ & 9,71 & 30,08 & 146,20 & 180,71 & 424,58 & 22,97 & 54,40 & 120,20 \\
\hline Frozen Raw Fruit 5 min & 6,22 & 22,75 & 229,22 & $\begin{array}{ll}155,37 \\
\end{array}$ & 790 & 20 & 56,35 & 224,57 \\
\hline Frozen Raw Fruit & 6,2 & 24 & 90,18 & 268 & 368 & 35 & 88,48 & 45,69 \\
\hline $\begin{array}{l}\text { Seedless Raw Fru } \\
\end{array}$ & 6,1 & 307,9 & 255,05 & 3126,47 & 473 & 314,31 & 738,73 & 32,30 \\
\hline Seedless Raw Fr & 8,9 & 376,4 & 352,40 & 3818, & 471 & 375,09 & 951,53 & 74,56 \\
\hline Seedless Raw Fruit 5 min & 6,84 & 424,30 & 350,05 & 4471 & 615 & 423,11 & 104 & 60,50 \\
\hline Seedless Raw Fruit 10 & 6,76 & 686,86 & 487,14 & 6751 & 635 & 628 & 1686,82 & 160,43 \\
\hline Seed $1 \mathrm{~min}$ & 6,88 & 47,66 & 149,64 & 865,4 & 573 & 100,78 & 211,40 & 54,72 \\
\hline & 7,09 & 67,08 & & & & & 235,47 & 70,07 \\
\hline d $5 n$ & $6,6,6$ & 76,59 & 145,41 & & 450,74 & 150 & 244,98 & \\
\hline Seed $10 \mathrm{mi}$ & 6,52 & 118,13 & 133,37 & 1697,29 & 513,23 & 192,05 & 361,44 & 40,07 \\
\hline
\end{tabular}

Table 2: LC MS/MS results of phenolic compounds ( $\mathrm{ng} / \mathrm{ml})$ of different samples with different boiling times

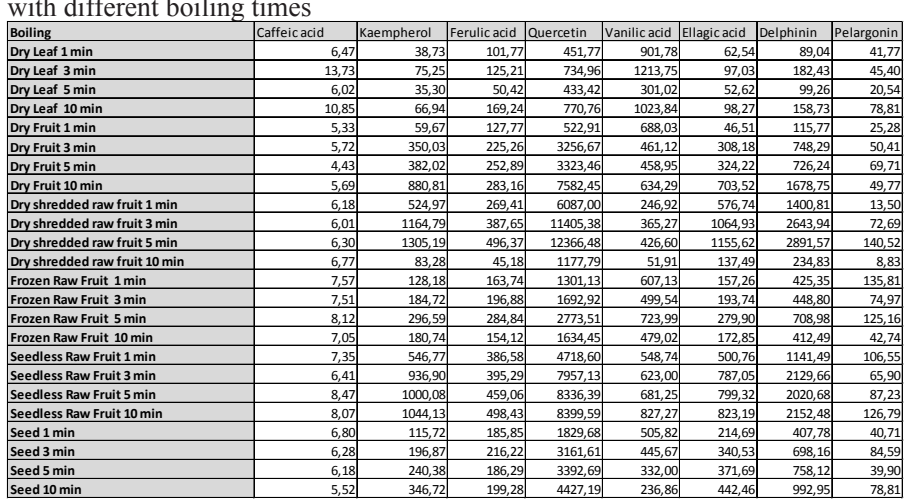

When the above tables were examined, the infusion method with the highest phenolic molecule content was determined as 5 minutes boiling of DSF. Therefore 5 min boiling DSF sample was used for cell culture studies. The IC50 values of bilberry extract was shown in Figure 1.

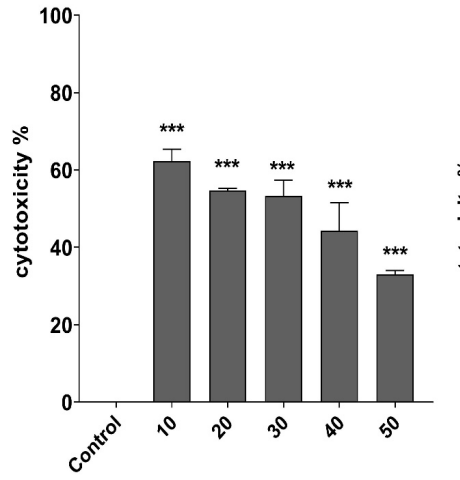

bilberry extract $(\mu \mathrm{g} / \mathrm{mL}), 24 \mathrm{~h}$

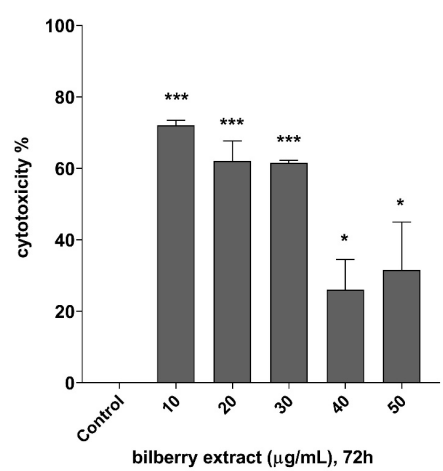

Figure 1: $\mathrm{IC}_{50}$ concentrations for bilberry extract in HCT-116 colon cancer cell culture. It was calculated for 3 different periods: (0-24 h, 24-48 h and 48-72 h). The IC50 values were $101,680 \mu \mathrm{g} / \mathrm{mL}, 80.676 \mu \mathrm{g} / \mathrm{mLand} 106,180 \mu \mathrm{g} / \mathrm{mL}$ in $24 \mathrm{th}$, 48th and 72th hours, respectively. As shown in Figure 1, the bilberry extract inhibited HCT-116 colon cancer cells proliferation in time-dependent manner with the highest IC50 (50\% inhibitory concentration) value of $80.676 \mu \mathrm{g} / \mathrm{ml}$ after $48 \mathrm{~h}$ treatment.

\section{HCT-116 Cell Line Apoptosis}

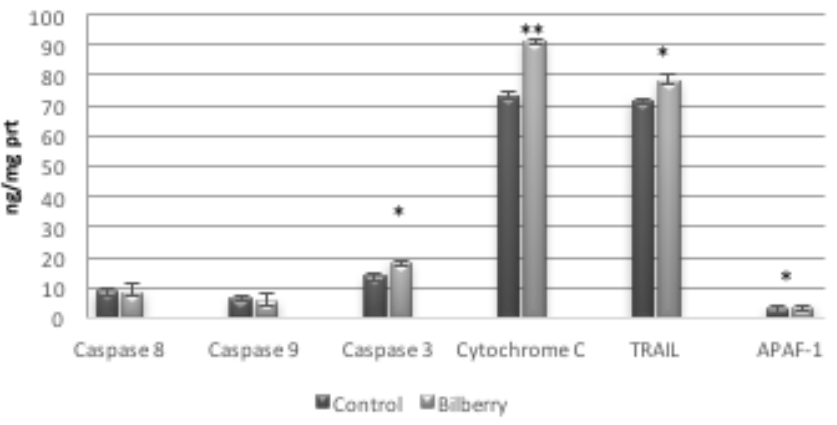

Figure 2: Effect of bilbery extract on apoptotic biomarkers in HCT-116 cell line; the levels of Caspase (-8, -9 -3), Cytochrome-c, TRAIL and APAF-1.

Cytotoxicity studies in cell culture were conducted using $50-10 \mu \mathrm{g} / \mathrm{ml}$ of bilberry tea samples which was prepared at a concentration of $5 \mathrm{~g} / 10 \mathrm{ml}$. As it can be seen from the Figure.2. The levels of APAF-1, TRAIL, Cytochrome-c and Caspase 3 were significantly higher in bilberry added cell culture than the control cells. Other markers (Caspase -8, -9 levels) did not show any significant change compared to control cells.

\section{DISCUSSION}

It is proposed that many compounds derived from natural plants act like chemical inhibitors in human cancer treatments, thus may have chemotherapeutic activity $(7,8,9)$. Some studies have shown that bilberries manifest antioxidant (12), antiinflammatory (13), antibacterial (10,14], hypoglycemic (15), antifungal (16), and antimutagenic (17) effects. In this study, the apoptotic effect of bilberry tea 
on HCT-116 colon cancer cell line was assessed.

The studies with natural compunds have shown that the different solvents, and the methods used to dissolve the plant or the fruit affects the study results related to active compounds in the plant or fruit studied. In the studies of Yildiz et al. (2011) related to Vaccinium myrtillus L., the structure of the biological active components of Vaccinium myrtillus L. were clarified, and, the collected fruits were stored at $-18^{\circ} \mathrm{C}$ for 1 week, and then dried at $40^{\circ} \mathrm{C}$ and pulverized. Dried fruits were extracted with methanol, ethanol, water and ethyl acetate, and left to stand in the stirrers with heater for 24 hours. The analyzes were performed by RC-HPLC. Researchers investigating the amount of phenolic compounds have found that the pehnolic content of plants show high variability due to the factors such as location, growing conditions, soil properties, irrigation, temperature and sunbathing. Previously, caffeic acid $(6.29 \pm 3.55 \mu \mathrm{g} / \mathrm{g})$, epicatechin $(8.35 \pm$ $5.04 \mu \mathrm{g} / \mathrm{g})$, and myricetin $(4.16 \pm 1.81 \mu \mathrm{g} / \mathrm{g})$, were found as the highest phenolic molecules in bilberry extracts $(2.10 \pm 0.64 \mu \mathrm{g} / \mathrm{g})(19)$. The most promising anticarcinogenic agents in plants are these phenolic compounds, which are abundantly present in Bilberries (Vaccinium myrtillus) (20).

In these studies, the bilberry fruits were extracted in the different types of solvents (water, ethanol and ethyl acetate), and their chemical compositions were identified using HPLC - DAD and HPLC-MS/MS method and the effects on antioxidant system were investigated using in-vitro analysis. In the result of these experimental studies, antiradical and antioxidant effects were found to be higher in ethanol, and ethyl acetate extracts, as well as high amounts of chemical compounds in these extracts.

The healthiest way of using these plant extracts is to solve them in water. therefore, boiling and brewing were used in our study. Since the studies have shown that brewing and boiling duration are effective in separating phenolic compounds from plants, we determined the phenolic content of bilberry fruits in different extraction times. Our data showed that the amount of obtained phenolic molecules vary depends on duration and extraction methods. Generally, the extracted amount was higher in boiling methods compared to those of brewing method and the highest phenolic molecule was quercetin both in two methods. In the study of León-González (2018), Anthocyanin- rich bilberry extract "Antho 50 " induced apoptosis and down-regulated the expression levels of different epigenetic proteins in human leukemia Jurkat cells. They observed that bilberry extract induced a redox-sensitive caspase-3- mediated apoptosis in chronic lymphocytic leukemia cells (21). In consistent with the mentioned study, the bilberry tea which include of kaempherol, quercetin, myricetine and delphinin in high concentration induce caspase-3 levels.

In our study, the extrinsic pathway in the HCT-116 colon cancer cell line is stimulated, which was confirmed with an increase in the TRAIL levels.

It has been suggested that ethanol extract of bilberry, rich in anthocyanins, inhibited the growth of HL60 human leukemia cells through the induction of apoptosis. When anthocyanidins and the anthocyanins isolated from bilberry extract were compared, the anthocyanins, mainly delphinidin- and malvidinglycosides caused apoptosis in the HL60 cells. The bilberry ethanol extract and certain anthocyanins inhibited the growth of HCT116 human colon carcinoma cells (22). In accordance with this study, bilberry tea sample having the high anthocyanins induced the apoptosis in our study.

In conclusion, the antioxidant and anticancer effect of natural products is related to its main phenolic content which are extracted by ethanol, water, methanol etc. The amount of extracted phenolic molecules might change due to extraction methods and extraction duration. Bilberry tea may contribute to maintain plasma levels of anthocyanins, which possess antioxidant activity and inhibitory effects on cancer cell growth via inducing apoptosis. Therefore, Bilberry tea might be suggested as a functional food for cancer treatment however further in vitro researchs need to clarify the required dose and effect of billberry tea.

Acknowledgments: The authors thank to "Ege University Research Foundation, 18-TIP 032" which give a support for this study.

Author Contributions: EYS designed the study\&prepared the study protocol. BD obtained literature data. HKY prepared the tea samples BD\&HM performed LC MS/MS analysis. BD, NSG, LO designed the experiments\&performed cell culture studies. ES, BD analysed the data.

\section{REFERENCES}

1. Demir S, Aliyazicioglu Y, et al. Antiproliferative and proapoptotic activity of Turkish propolis on human lung cancer cell line. Nutr Cancer 2016; 68(1) :165172.

2. Kathiresan K, Boopathy N.S and Kavitha S. Coastal vegetation-an underexplored source of anticancer drugs. NPR 2006; 5:115-119.

3. Yilmaz H. H, et al. Cancer trends and incidence and mortality patterns in Turkey. JOCR 2010; 41(1):10-16.

4. Milosevic C, et al. Antiproliferative effects of some medicinal plants on HeLa cells. ARCH BIOL SCI 2013; 65 (1):65-70.

5. Rosangkima G, Prasad S.B. Antitumour activity of some plants from Meghalaya and Mizoram against murine ascites Dolton`s lymphoma. IJEB 2004; 42:981-988 6. Mehta R. G, Murillo G, Naithani R, \& Peng X. Cancer chemoprevention by natural products: how far have we come? JPR 2010; 27(6):950-961.

7. Eggler A.L, Gay K.A, Mesecar A.D. Molecular mechanisms of natural products in chemoprevention: induction of cytoprotective enzymes by Nrf2.Mol Nutr Food Res 2008; 52(Suppl1): S84-S94.

8. Shen S, Zhang Y, Zhang R, Tu X, Gong X. Ursolic acid induces autophagy in U87MG cells via ROSdependent endoplasmic reticulum stress. Chem-Biol Interact 2014; 218:28-41.

9. Surh Y.J. Cancer chemoprevention with dietary phytochemicals. Nat 2003; Rev.

10. Aleksic V, Knezevic P. Antimicrobial and antioxidative activity of extracts and essential oils of Myrtus communis L. Microbiol Res 2014; 169:240-54

11. Montoro P, Tuberoso C, Piacente S, Perrone A, De Feo V, et al. Stability and antioxidant activity of polyphenols in extracts of Myrtus communis L. berries used for the preparation of myrtle liqueur. JPBA 2006; 41:1614-9

12. Gardeli C, Vassiliki P, Athanasios M, Kibouris T, Komaitis M. Essential oil composition of Pistacia lentiscus L. and Myrtus communis L.: Evaluation of antioxidant capacity of methanolic extracts. Food Chem 2008; 107:1120-30

13. Calomme M, Pieters L, Vlietinck A, Vanden Berghe D. Inhibition of bacterial mutagenesis by Citrus flavonoids. Planta Med 1996; 62:222-6

14. Rossi A, Di Paola R, Mazzon E, Genovese T, Caminiti R, et al. Myrtucommulone from Myrtus communis exhibits potent anti-inflammatory effectiveness in vivo. J Pharmacol Exp Ther 2009; 329:76-86

15. Rotstein A, Lifshitz A, Kashman Y. Isolation and Antibacterial Activity of Acylphloroglucinols from Myrtus communis. AAC 1974; 6:539-42

16. Nassar MI, Aboutabl el SA, Ahmed RF, El-Khrisy ED, Ibrahim KM, et al. Secondary metabolites and bioactivities of Myrtus communis. Pharmacognosy Res 2010; 2:325-9

17. Curini M, Bianchi A, Epifano F, Bruni R, Torta L, et al. Composition and in vitro Antifungal Activity of Essential Oils of Erigeron canadensis and Myrtus communis from France. Chem Nat Compd 2003; 39:191-4

18. Yıldız A. Trabzon yöresine ait yaban mersini (Vaccinium myrtillus L.)'nin hplc ile fenolik yapısının aydınlatılması ve antioksidan özelliklerinin belirlenmesi. Yüksek lisans tezi, KTU FBE 2011; Trabzon,1-2s

19. Alhosin M, LeónGonzález AJ, Dandache I, Lelay A, Rashid SK, Kevers C, Pincemail J, Fornecker LM, Mauvieux L, Herbrecht R and SchiniKerth VB. Bilberry extract (Antho 50) selectively induces redoxsensitive caspase 3related apoptosis in chroniclymphocytic leukemia cells by targeting the $\mathrm{Bcl} 2 / \mathrm{Bad}$ pathway. Sci Rep 2015; 5: 8996.

20. Kim J, Kim CS, Lee YM, Sohn E, Jo K and Kim JS. Vaccinium myrtillus extract prevents or delays the onset of diabetesinduced bloodretinal barrier breakdown. Int J Food Sci Nutr 66: 23642, 2015

21. León-González A. J, Sharif T, Auger C, Abbas M, Fuhrmann G, \& SchiniKerth V. B. Anthocyanin-rich bilberry extract induces apoptosis in acute lymphoblastic leukemia cells via redox-sensitive epigenetic modifications. J Funct Foods 2018; 44:227-234.

22. Katsube N, Iwashita K, Tsushida T, Yamaki K, \& Kobori M. Induction of apoptosis in cancer cells by bilberry (Vaccinium myrtillus) and the anthocyanins. $\mathrm{J}$ Agric Food Chem 2003; 51(1):68-75. 
XXVII. Balkan Clinical Laboratory Federation Meeting BCLF 2019

XXX. National Congress of the Turkish Biochemical Society TBS 2019

Development and validation of a biosensor for measurement of serum hypoxia-inducible factor-1

[Serum hipoksi ile indüklenebilir faktör-1'in ölçülmesi için bir biyosensör geliştirilmesi ve validasyonu]

Zihni Onur UYGUN ${ }^{1 *}$, Hilmiye Deniz ERTUĞRUL UYGUN ${ }^{2,3}$, Sinem Nur ŞENGÖZ COŞKUN ${ }^{4}$, Şevki ÇETINKALP ${ }^{5}$, Yasemin AKÇAY ${ }^{1}$, Ferhan GİRGIN SAĞIN ${ }^{1}$

${ }^{1}$ Ege University, Faculty of Medicine, Medical Biochemistry Department, Bornova, 35100, İzmir, Turkey

${ }^{2}$ Dokuz Eylül University, Center for Fabrication and Application of Electronic Materials, Buca, 35390, İzmir, Turkey

${ }^{3}$ Dokuz Eylül University, Institue of Science, Nanoscience and Nanoengineering Dept. Buca, 35390, İzmir, Turkey

${ }^{4}$ Cukurova University, Balcalı Hospital Health Application and Research Center, Department of Endocrinology and Metabolism, Adana, Turkey

${ }^{5}$ Ege University, Faculty of Medicine, Department of Internal Medicine, Endocrynology Division, Bornova, 35100, İzmir, Turkey

*Corresponding Author: onur.uygun@ege.edu.tr

\section{Abstract}

Objectives: Normal oxygen delivery is essential for survival. Hypoxia, which is a common feature of various pathological conditions, ranging from cancer to inflammatory diseases, occurs when normal oxygen delivery is altered by an imbalance between cellular oxygen demand and tissue oxygen supply. Among the intricate mechanisms organisms have developed to maintain oxygen homeostasis, a family of hypoxia-inducible transcription factors (HIFs), are found to be the main regulator adaptive cellular response to hypoxia. Although ELISA can be used for its measurement, the lability of the protein and length of the analysis ( $>5$ hours) pose limitations. Thus, our aim is to develop an electrochemical impedance spectroscopy (EIS) based biosensor system for quick and reliable measurement of HIF-1 $\alpha$ in serum.

Materials and Methods: HIF-1alpha antibodies have been used as a biorecognition receptor. For immobilization, the electrode was first modified with albumin, followed by PAMAM. The new biosensor was compared with the conventional ELISA method.

Results: Based on the chronoimpedance data, total analysis time for EIS was chosen as 15 minutes. Calibration curve was constructed by locating electron transfer resistance on y-axis and HIF1 concentration on x-axis, between 50-1000 $\mathrm{pg} / \mathrm{mL}$. LOD and LOQ of the biosensor were calculated as $14.45 \mathrm{pg} / \mathrm{mL}$ and $43.8 \mathrm{pg} / \mathrm{mL}$, respectively. The new biosensor showed very good correlation when compared with the conventional ELISA method $(\mathrm{R} 2=0.99649)$.

Conclusion: We developed and analytically validated a biosensor system to measure HIF-1 $\alpha$ in serum. This new biosensor promises more timely and accurate measurements in determining the tissue oxygenation in patients who have hypoxia related conditions such as diabetic foot.

Keywords: hypoxia inducible factor 1 alpha, biosensor, impedance, PAMAM

\section{Özet}

Amaç: Normal oksijen iletimi hayatta kalmak için esastır. Kanserden inflamatuvar hastalıklara kadar çeşitli patolojik durumların ortak bir özelliği olan hipoksi, normal oksijen iletiminin hücresel oksijen talebi ile doku oksijen beslenmesi arasındaki dengesizlik sonucu etkilenmesiyle meydana gelir. Organizmaların oksijen homeostazını korumak için geliştirdiği kompleks mekanizmalar arasında, hipoksiye karşı ana düzenleyici hücresel uyum yanıtının hipoksi ile indüklenebilir transkripsiyon faktörleri ailesi (HIF) olduğu bulunmuştur. Her ne kadar ELISA ölçümü bu belirteç için kullanılabilse de, proteinin labil doğası ve analiz süresinin uzunluğu (> 5 saat) bu ölçüme sınırlamalar getirir. Bu nedenle amacımız serumda HIF-1 $\alpha$ 'nın hızlı ve güvenilir ölçümü için elektrokimyasal empedans spektroskopisi (EIS) bazlı biyosensör sistemi geliştirmektir.

Gereç ve Yöntem: HIF-1 alfa antikorları, biyotanıma reseptörü olarak kullanılmıştır. İmmobilizasyon için elektrot önce albümin, ardından PAMAM ile modifiye edilmiş ve geliştirilen yeni biyosensör, geleneksel ELISA yöntemiyle karşılaștırılmıștır.

Bulgular: Kronoimpedans verilerine dayanarak, EIS için toplam analiz süresi 15 dakika olarak seçilmiştir. Kalibrasyon eğrisi, y-ekseni üzerindeki elektron transfer direnci, $\mathrm{x}$ ekseni üzerinde HIF-1 konsantrasyonu 50-1000 pg/mL arasında yerleştirilerek yapılmıştır. Biyosensörün LOD ve LOQ değerleri sırasıyla 14,45 $\mathrm{pg} / \mathrm{mL}$ ve $43,8 \mathrm{pg} / \mathrm{mL}$ olarak hesaplanmıştır. Yeni biyosensör, geleneksel ELISA yöntemiyle karşılaştırıldığında çok iyi bir korelasyon göstermiştir $\left(\mathrm{R}^{2}=0,99649\right)$.

Sonuç: Bu çalışmayla, serumda HIF-la'yı ölçmek için bir biyosensör sistemi geliştirilmiş ve sistemin etkinliği analitik olarak doğrulanmıştır. Bu yeni biyosensör, diyabetik ayak gibi hipoksi ile ilişkili rahatsılılıları bulunan hastalarda doku oksijenasyonunun belirlenmesinde daha kısa zamanda ve daha doğru ölçümler vermeyi vaat etmektedir.

Anahtar Sözcükler: hipoksi indüklenebilir faktör 1 alfa, biyosensör, empedans, PAMAM

\section{Introduction}

Normal oxygen delivery is essential for survival. Recently, 2019 the Nobel Prize in Medicine (or Physiology) was given to three scientists for their studies on adaptation of the organism in hypoxic conditions [1]. There are different biomarkers that can show the level of hypoxic conditions and one of them is hypoxia-inducible factor-1 (HIF-1). HIF-1 is a transcription factor that plays a key role in the development of adaptation response to hypoxia. The molecule consists of the subunits HIF-1 $\alpha$ and HIF-1 $\beta$ [2]. HIF-1 $\alpha$ is the main regulator of oxygen homeostasis and adaptive cellular response to hypoxia to regulate cell survival [3]development, physiology, and pathobiology. The hypoxia-inducible factors (HIFs. It is activated by a decrease in oxygen concentration of the cell and targets many genes in various pathways; erythropoiesis, iron metabolism, angiogenesis, glucose metabolism, vascular tonus, matrix metabolism, cell survival, proliferation and apoptosis. Studies have shown that HIF-1 $\alpha$ dysfunction occurs in the hyperglycemic environment in diabetic individuals as a result of disruption of transactivation. The increased level of reactive oxygen radicals in the hypoxic environment inhibits HIF-1 $\alpha$ gene expression. Interestingly, some HIF-1 $\alpha$ polymorphisms were found to be significantly higher in diabetic foot ulcer patients when compared to that of healthy controls, so these mutations can be important in the pathogenesis of diabetic foot wound under hypoxic conditions [4]. The conventional method for HIF-1 $\alpha$ analysis is the ELISA which has some limitations due to length of the analysis ( $>5$ hours) and the lability of the protein. Besides matrix effects like hemolysis, hyperlipidemia can also alter the measurement accuracy in the ELISA system. Thus, our aim was to develop an electrochemical impedance spectroscopy (EIS) based biosensor system for quick and reliable measurement of HIF-1 $\alpha$ in serum.

Impedimetric biosensors are developed by immobilization of a receptor; an antibody, DNA or protein molecule, which show affinity only to the analyte molecule. The signals resulting from the interaction between this biological sensor and the analyte molecule are transmitted by the physicochemical transducer to the analysis system and measurement can be performed by analyzing the concentration-dependent response of these signals obtained through EIS [5]Biosensor technology has provided a number of benefits to detect both biological and chemical molecules. Abiosensor is a promising device, which is combination of sensitivity of electrochemistry and specificity of biological recognition, enables to detect any kind of molecules in a short time with selectively and sensitively. Likewise many analytical methods, it has also limitations, such as high oxidation potentials lead to detection of non-target molecules, furthermore non-electroactive species cannot show electroactive signal for measurement or some biomolecules cannot be transformed by enzymes, even if they can be transformed, they require secondary molecules such as mediators, coenzymes or labels. In order to detect molecules without electrochemical reaction, electrochemical impedance spectroscopy (EIS. In recent years, EIS has been able to make highly sensitive measurements as a sensing system especially in the development of biosensor technologies based on immunological based biomolecule interactions[6]. In EIS, the liquid interface properties and the binding parameters to the electrode surface can be measured. Since the EIS can measure the thickness or charge distribution (capacitance) of the electrode surface, it can be very sensitive to detect even very small changes that alter the electrical charge distribution on the electrode. Electrode surface resistance with EIS can be measured using potentiostat without any biochemical reactions. The color and turbidity properties of the measured fluid do not affect the measurement.

In the light of the above background, we immobilized HIF-1 antibodies which are capable of recognizing HIF-1 on the screen printed electrode surface (the sensor system). Thus, the new electrodes we developed had a more specific and rapid measurement capacity since a direct affinity based bioreceptor was used for the 
target molecule HIF-1. The measurement of the binding of HIF-1 to the antiHIF-1 on the electrode was performed by using surface-characterization EIS and the results were obtained with concentration-time-impedance function. In order to evaluate the validity of our measurement, results, procedure and performance characteristics were compared with the conventional ELISA technique.

\section{Materials and Methods}

Materials

All chemical materials were obtained from Sigma-Aldrich(USA). Electrochemical measurements were performed using the PalmSens 3 potentiostat (Palmsens BV, The Netherlands). Screen printed gold electrodes (250 AT) were obtained from Dropsens (Spain). All chemicals were prepared using triple deionized water. Blood samples were taken from the control group and severe diabetic patients in whom amputation was planned. Serum were stored at $-20^{\circ} \mathrm{C}$ until use. The study was approved by the Ethics Research Committee (16-9/15) of

Ege University School of Medicine and supported by the Ege University Scientific Research Projects Commission (18-TIP-036).

\section{Methods}

This study included the archive blood of 30 patients between the ages of 18 and 100 who participated in the Diabetic Foot Council which is being held every Wednesday at Ege University Faculty of Medicine Orthopedic Policlinic within the scope of approval of the ethics committee numbered 16-9/15. HIF-1 $\alpha$ levels were measured by both ELISA and biosensor we developed in the Department of Medical Biochemistry. The basis of this study is based on the immobilization of antibodies, specific molecules, to the surface after modification of the transducer surface and subsequent electrochemical examination of the surface due to the affinity between the HIF-1 molecule and the antibody. The bonding result of this affinity changed the electrical properties of the surface and after the change of electrical properties acceptable signals were obtained and electrochemical measurement was performed by electrochemical impedance spectroscopy and chronoimpedance. The electron transfer resistance was measured in redox probe solution, this measurement was calculated Randless circuit model [7]. $\mathrm{R}_{2}$; represents the electron transfer resistance of the electrode surface. Since this resistance will change by binding of HIF- $1 \alpha$ to the immobilized anti-HIF- $1 \alpha$ on the electrode surface, the EIS values based on this have also changed. First of all, the gold nanoparticle modified electrode was placed in a cap containing water and ethanol (1:1) and left in a sonic bath for 2 minutes to remove impurities. Then, it was washed with pure water and dried under nitrogen gas. The gold nanoparticles were deposited on the surface by applying $-200 \mathrm{mV}$ to the electrode immersed in a solution containing $200 \mathrm{ppm}$ AuNPs. The electrode was then gently washed with distilled water and dried with nitrogen gas. AuNPs/BSA modification was carried out by the following modifications $50 \mu \mathrm{L}$ of $1 \mathrm{mg} / \mathrm{mL}$ BSA solution was placed on the surface of the gold nanoparticle coated electrode and incubated for 1 hour. AuNPs/BSA/PAMAM modification was carried out as follows; BSA on AuNPs was activated with $5 \%$ glutaraldehyde for 30 minutes and $5 \mathrm{mM} 50 \mu \mathrm{L}$ of PAMAM was dropped onto the surface and incubated for 1 hour. The electrode was washed with distilled water and gently dried with nitrogen gas. AuNPs/ BSA/PAMAM/anti-HIF- $1 \alpha$ modification was carried out via $\mathrm{NH}_{2}$ ends on the AuNPs/BSA/PAMAM electrode by activating $5 \%$ gluaraldehyde and subsequent incubated by dropping anti-HIF-1 $\alpha$ on electrode. After the electrode was washed, the unbonded anti-HIF- $1 \alpha$ removed. All modification steps were investigated by electrochemical impedance spectroscopy.

\section{Results}

All EIS curves of the electrode modification are shown in Figure 1 (Figure 1). The GNP modified electrode is shown in green. The BSA coating was used for covalent PAMAM modification by immobilization and $\mathrm{pH}$ stabilization of the surface of the electrode. As can be seen, an increase in electron transfer resistance was observed with coating of the surface. This is an expected result. The red curve shows the BSA layer. BSA has been used because of the ability of gold nanoparticles to attract proteins to the surface. Glutarladehide was used for covalent bonding of the next immobilization material (PAMAM) by activating amine groups on BSA. PAMAM-G5 is the fifth generation demdrimer class for electrode surface. This molecule is formed by branching ethylenediamine 5 times over the ethylene diamine nucleus and having amino groups at the end. This is also suitable for covalent bonding of BSA-PAMAM via glutaraldehyde. Since gold nanoparticles are nanomaterials, they are used in our biosensor system to facilitate electron transfer and increase surface area and provide active immobilization. PAMAM material was used to increase electrode surface area to immobilize more anti-HIF antibodies to increase sensitivity. In PAMAM bonding, because the surface is positively charged, it draws the negatively charged redox probe electrostatically to the surface, thereby increasing mass transfer, that is, Warburg impedance, increasing the electron transfer resistance on the electrode surface. The amino termini of PAMAM are reactivated with glutaraldehyde, making it suitable for anti-HIF binding. After activation of the PAMAM tips, anti-HIF was dropped onto the surface and covalently bonded to the surface. Since the anti-HIF immobilization increases the electron transfer resistance of the surface by forming an isolation layer, an increase in the impedance signal has occurred (Figure 1).

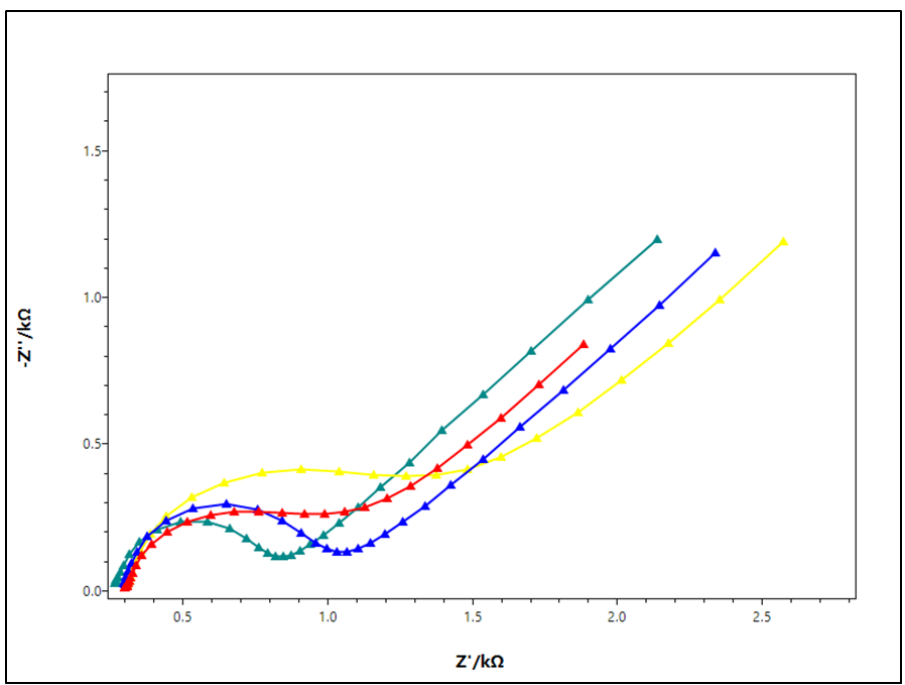

Figure 1. Red curve GNPE, Yellow curve GNPE / BSA, green curve GNPE BSA / PAMAM, Blue curve GNPE / BSA / PAMAM / Anti-HIF1alpha modified electrode EIS curves.

Figure 2 shows that the conductivity of the gold nanoparticle electrode is high and the Warburg impedance is dominant. An increase in impedance occurred when the surface was coated with BSA. Although PAMAM coating is expected to increase in flowing impedance, since the PAMAM layer is positively charged at $\mathrm{pH}=7$, the electron transfer resistance is reduced by pulling the negatively charged redox probe and increasing the number of redox probes that are electrochemically transformed per unit time. Anti-HIF1 binding also increases the electron transfer resistance. These procedures show that immobilization procedures are performed very successfully.

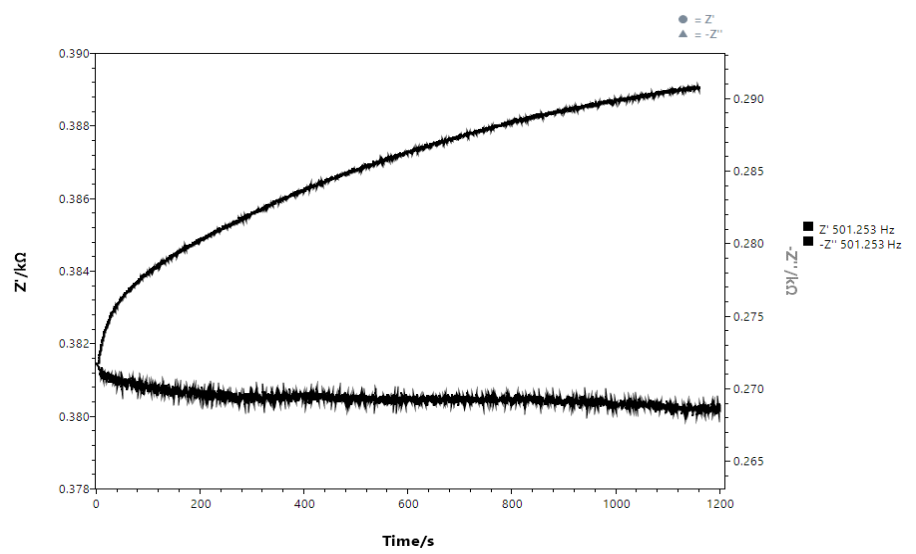

Figure 2. GNPE / BSA / PAMAM / AntiHIF1 a: 900mV 200Hz buffer and b: 900mV $200 \mathrm{~Hz}$ HIF1.

After 40 seconds, the impedance curve began to gain linearity and continued linearly, although the binding speed was low. Therefore, the detection time is optimized for 10 minutes.

For calibration curves, 13 calibration curves were prepared to evaluate electrode performance characteristics such as GNPE/BSA/PAMAM/Anti-HIF1 modified biosensor Repeatability, selectivity, repeatability, linear spacing, LOQ, and LOD were performed (Figure $3 \mathrm{~A}$ and $\mathrm{B}$ ).

Comparison of the newly developed biosensor with the conventional ELISA method is given in Table 1 . 
XXVII. Balkan Clinical Laboratory Federation Meeting BCLF 2019

XXX. National Congress of the Turkish Biochemical Society TBS 2019

Table 1. Comparison of the ELISA and the Biosensor

\begin{tabular}{|lll|}
\hline Parameters & HIF 1 Biosensor & ELISA \\
\hline Sample & Serum & Serum \\
\hline Linear Range & $50-1000 \mathrm{pg} / \mathrm{mL} R^{2}=0,9964$ & $81,92-20000 \mathrm{pg} / \mathrm{mL}$ \\
\hline LOD & $14,45 \mathrm{pg} / \mathrm{mL}(3,3(\mathrm{~S}($ Ret $=50 \mathrm{pg} / \mathrm{mL}) / \mathrm{m})$ & $<30 \mathrm{pg} / \mathrm{mL}$ \\
& & - \\
\hline LOQ & $43,8 \mathrm{pg} / \mathrm{mL}(3,3(\mathrm{~S}($ Ret $=50 \mathrm{pg} / \mathrm{mL}) / \mathrm{m})$ & - \\
\hline Reproducible & $\mathrm{R}^{2}=0.9964 \pm 0.0024(\mathrm{n}=13)$ & - \\
\hline Repeatibility & $1 .($ Serum $\mathrm{n}=3,53,3): 51,6 \pm 1,41(\mathrm{pg} / \mathrm{mL})$ & \\
& 2. (Serum $\mathrm{n}=3,101,13) 100,3 \pm 3,84(\mathrm{pg} / \mathrm{mL})$ & \\
\hline Detection Time & 10 Minutes & \\
& & \\
\end{tabular}

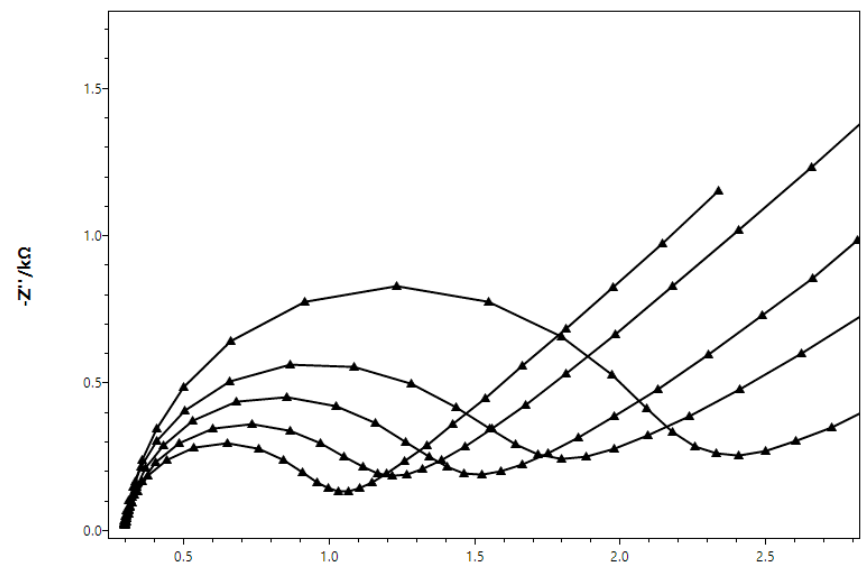

$\mathrm{Z}^{\prime} / \mathrm{k} \Omega$

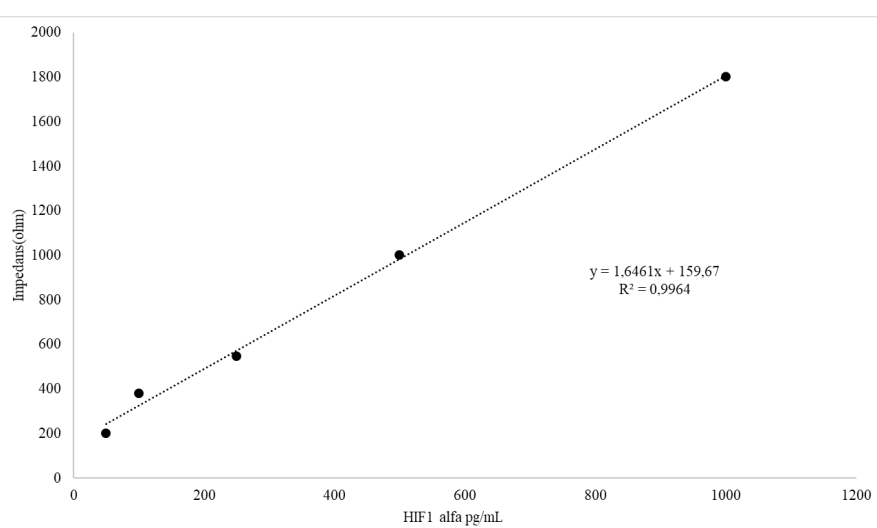

Figure 3. A: Impedance curve of the calibration curve of the HIF1 biosensor from $50 \mathrm{pg} / \mathrm{mL}$ to $1000 \mathrm{pg} / \mathrm{mL}$. B: Calibration curve of the HIF1 biosensor (y- $\Delta$ Ret, x-HIF (pg / mL.min)), R2 =0.9964.

Supplementary Table 1 shows amputation and diabetes mellitus (DM) and amputation levels (Suppl. Table 1). HIF1 values $(\mathrm{pg} / \mathrm{mL})$ were also measured. HIF measurements using archive blood repeats from these patients in previous studies were performed using ELISA kit.

\section{Conclusion}

In this study, HIF1 alpha biosensor has been successfully developed for the first time in the literature. Our studies also include chrono-impedance studies to characterize the impedimetric detection time. The success of the biosensor in real serum samples also makes it possible to commercialize the biosensor after its development. The LOQ limit confirms that the calibration curve is close to the theoretical level. Selectivity studies using real serum samples and electrodes show good selectivity against serum samples. In the reproducibility study, when 13 calibration curves were prepared and the standard deviation of R2 values were taken, extremely low standard deviation showed that the system was both reproducible and reproducible. As a result, we have successfully developed our biosensor system by achieving our goal.

\section{References}

1. The 2019 Nobel Prize in Physiology or Medicine - Press release. https://www. nobelprize.org/prizes/medicine/2019/press-release/. Accessed 13 Oct 2019 2. Rey S, Semenza GL (2010) Hypoxia-inducible factor-1-dependent mechanisms of vascularization and vascular remodelling. Cardiovasc Res 86:236-242. https:// doi.org/10.1093/cvr/cvq045

3. Semenza GL, Beall CM, Cavalleri GL, et al (2012) Hypoxia-inducible factors in physiology and medicine. Cell 148:399-408. https://doi.org/10.1016/j. cell.2012.01.021

4. Pichu S, Sathiyamoorthy J, Krishnamoorthy E, et al (2015) Impact of the hypoxia inducible factor- $1 \alpha$ (HIF-1 $\alpha$ ) pro582ser polymorphism and its gene expression on diabetic foot ulcers. Diabetes Res Clin Pract 109:533-540. https:// doi.org/10.1016/j.diabres.2015.05.014

5. Deniz H, Onur Z (2013) Impedimetric Biosensors for Label-Free and Enzymless Detection. In: State of the Art in Biosensors - General Aspects. InTech 6. Uygun ZO, Sezgintürk MK (2011) A novel, ultra sensible biosensor built by layer-by-layer covalent attachment of a receptor for diagnosis of tumor growth. Anal Chim Acta 706:343-348. https://doi.org/10.1016/J.ACA.2011.08.044

7. Randles JEB (1947) Kinetics of rapid electrode reactions. Discuss Faraday Soc 1:11. https://doi.org/10.1039/df9470100011

Supplementary Table 1. HIF-1a levels in DM and amputation samples

\begin{tabular}{|c|c|c|c|c|}
\hline Patient & $\begin{array}{l}\text { DM } \\
\text { Type }\end{array}$ & DM Duration (Year) & Amputation Level & $\mathrm{HIF}-1 \alpha(\mathrm{pg} / \mathrm{mL})$ \\
\hline Patient 1 & Type-2 & 35 & Finger & 341.67 \\
\hline Patient 2 & Type-2 & 6 & Transmetatarsal & 351.23 \\
\hline Patient 3 & Type-2 & 1 & Above Knee & 673.77 \\
\hline Patient 4 & Type-2 & 3 & Transmetatarsal & 64.23 \\
\hline Patient 5 & Type-2 & 30 & Finger & 79.27 \\
\hline Patient 6 & Type-2 & 32 & Under the Knee & 101.13 \\
\hline Patient 7 & Type-2 & 25 & Finger & 54.67 \\
\hline Patient 8 & Type-2 & 18 & Finger & 58.77 \\
\hline Patient 9 & Type-2 & 45 & Finger & 43.73 \\
\hline Patient 10 & Type-2 & 14 & Under the Knee & 60.13 \\
\hline Patient 11 & Type-2 & 15 & Chopart & 57.4 \\
\hline Patient 12 & Type-2 & 7 & Under the Knee & 53.3 \\
\hline Patient 13 & Type-2 & 2 & Finger & 60.13 \\
\hline Patient 14 & Type-2 & 22 & Finger & 102.5 \\
\hline Patient 15 & Type-1 & 40 & Under the Knee & 639.6 \\
\hline Patient 16 & Type-2 & 23 & Under the Knee & 49.2 \\
\hline Patient 17 & Type-2 & 25 & Transmetatarsal & 82 \\
\hline Patient 18 & Type-2 & 30 & Finger & 57.4 \\
\hline Patient 19 & Type-2 & 20 & Under the Knee & 57.4 \\
\hline Patient 20 & Type-2 & 40 & Transmetatarsal & 60.13 \\
\hline Patient 21 & Type-2 & 27 & Under the Knee & 169.47 \\
\hline Patient 22 & Type-2 & 2 & Under the Knee & 58.77 \\
\hline Patient 23 & Type-2 & 16 & Under the Knee & 155.8 \\
\hline Patient 24 & Type-2 & 20 & Under the Knee & 57.4 \\
\hline Patient 25 & Type-2 & 4 & Under the Knee & 50.57 \\
\hline Patient 26 & Type-2 & 15 & Transmetatarsal & 61.5 \\
\hline
\end{tabular}


XXVII. Balkan Clinical Laboratory Federation Meeting BCLF 2019

XXX. National Congress of the Turkish Biochemical Society TBS 2019

\section{Reelin enzyme levels in patients admitted to emergency service due to suicide or self-harm attempt}

$\underline{\text { Turgut Dolanbay }}^{1 *}$, Mustafa Y1lmaz ${ }^{2}$, Mehtap Gurger ${ }^{2}$, Metin Atescelik², Mehmet Cagrı Goktekin ${ }^{2}$, Nevin Ilhan ${ }^{3}$, Huseyin Fatih Gul ${ }^{4}$

${ }^{1}$ Department of Emergency Medicine, Kafkas University Health Research and Application Hospital, Kars, Turkey

${ }^{2}$ Department of Emergency Medicine, Firat University School of Medicine, Elazig, Turkey

${ }^{3}$ Department of Medical Biochemistry, Faculty of Medicine, Firat University, Elazig, Turkey

${ }^{4}$ Department of Medical Biochemistry, Faculty of Medicine, Kafkas University, Kars, Turkey

\section{Abstract}

Background: Every year more than one million people commit suicide worldwide. Suicide cases constitute $1-2 \%$ of the total global mortality. Reelin is an extracellular matrix glycoprotein and involved in the development of brain layers during embryogenesis. Reelin is linked with several psychiatric diseases but not investigated in the suicide cases.

Objectives: We aimed to investigate reelin enzyme levels among suicide patients in comparison to the heathy controls.

Materials and Methods: A total 86 suicide cases and 100 healthy controls were included in the study. Serum reelin levels were determined by using commercial Human ELISA kit. Demographic variables and clinic data were collected and analyzed.

Results: Body mass index and mean age among groups were significantly different. While the median reelin enzyme level of Suicide Group was 3038,31 (IQR:212,46-8044,21) ng/L and that of Control Group was 2271,20 (IQR:77,67$7647,83) \mathrm{ng} / \mathrm{L}$. The difference was statistically significant $(\mathrm{p}<0.01)$.

Conclusions: According to the results of this study, reelin enzyme level of suicide patients was found to be significantly higher than normal cases. The importance and impact of our findings on suicide needs to be investigated across different populations.

Keywords: Suicide, Reelin, Emergency Service, ELISA, self-harm

Kendine zarar verme veya özkıyım girişimi nedeniyle acil servise başvuran hastalarda reelin enzim düzeylerinin araştırılması

$\underline{\text { Turgut Dolanbay }}^{1 *}$, Mustafa Yılmaz ${ }^{2}$, Mehtap Gürger ${ }^{2}$, Metin Ateşçelik $^{2}$, Mehmet $^{2}$ Çağrı Göktekin ${ }^{2}$, Nevin İlhan ${ }^{3}$, Hüseyin Fatih Gül ${ }^{4}$

${ }^{1}$ Kafkas Üniversitesi, Tıp Fakültesi, Acil Tıp Ana Bilim Dalı, Kars, Türkiye

${ }^{2}$ Fırat Üniversitesi, Tıp Fakültesi, Acil Tıp Ana Bilim Dalı, Elazı̆̆, Türkiye

${ }^{3}$ Fırat Üniversitesi, Tıp Fakültesi, Tıbbi Biyokimya Ana Bilim Dalı, Elazığg, Türkiye

${ }^{4}$ Kafkas Üniversitesi, Tıp Fakültesi, Tıbbi Biyokimya Ana Bilim Dalı, Kars, Türkiye

Özet

Giriș: Her yıl dünya çapında bir milyondan fazla insan intihar etmektedir ve intihar vakaları toplam küresel ölümlerin \%1-2'sini oluşturmaktadır. Reelin hücre dışı bir matriks glikoproteinidir ve embriyojenez sırasında beyin tabakalarının gelişimine katılmaktadır. Reelin birçok psikiyatrik hastalıkla ilişkilendirilmesine rağmen intihar vakalarıyla ilişkilendirilmemiştir.

Amaç: Bu çalışmada intihar girişimininde bulunan hastaların reelin enzim düzeylerinin sağlıklı kontrollerle kıyaslanması amaçlanmıştır.

Materyal ve Metot: Çalışmada toplam 86 intihar girişimininde bulunmuş hasta ile 100 sağlıklı kontrol kullanıldı. Serum örneklerinde reelin düzeyleri, Human ELISA kiti kullanılarak kit prosedürüne uygun olarak incelendi. Demografik değişkenler ve klinik veriler de toplandı ve karşılaştırıldı.

Bulgular: Gruplar arasındaki vücut kitle indeksi ve yaş ortalaması farklılıkları istatistiksel olarak anlamlı bulunmuştur. İntihar Grubu'nun ortanca reelin enzimi değeri 3038,31 (IQR: 212,46-8044,21) ng/L iken, Kontrol Grubunda bu değer 2271,20 (IQR: 77,67-7647,83) ng/L olarak bulunmuş olup aradaki fark istatistiksel olarak anlamlidir $(\mathrm{p}<0.01)$.

Sonuç: Bu çalıșmanın sonuçlarına göre intihar hastalarında reelin enzim düzeyi normal vakalardan anlamlı derecede yüksek bulunmuştur. Bulgularımızın intihar üzerindeki önemi ve etkisi farklı popülasyonlarda da (daha yüksek veri ile) araştırılmalıdır.

Anahtar Sözcükler: İntihar, Reelin düzeyi, Acil Servis, ELISA, Kendine zarar verme

\section{Introduction}

Suicide is the self-injury with an aim to achieve death and is frequently encountered in emergency services and intensive care units [1]. Every year, more than one million people commit suicide worldwide and suicide cases constitute $1-2 \%$ of the total global mortality [2]. Most people who are on the verge of suicide tend to express their thoughts and intent. They use expressions that indicate desire to die and give signs that they feel worthless $[3,4]$. These are requests for assistance in suicidal cases. The thoughts and movements of people are limited just before the suicide as they consider suicide continuously and cannot perceive the other solutions for their problem(s) [3]. Suicide risk is increased 3-12 times among those with a history of psychiatric diseases compared to those without one [5]. Approximately $95 \%$ of people who have accomplished suicide have a history of psychiatric disease and the increase in frequency of suicide in some psychiatric diagnostic groups is noteworthy [4].

The gene encoding reelin is located on human chromosome 7 (7q22) and produces a protein with a molecular weight of $388 \mathrm{kDa}$. Reelin is an extracellular matrix glycoprotein involved in the development of brain layers during embryogenesis [6]. Reelin proteins are secreted from different regions of the brain, particularly Cajal-Retzius cells in the cortex and marginal zone of hippocampus. Reelin is not only secreted from the brain in the developmental process but is also secreted in adults from the glutamatergic granulated cells in the cortex and hippocampus GABAergic neurons in the cerebellum [7]. A number of studies indicated deficiency of the reelin in various neuropsychiatric diseases such as epilepsy, autism, major depression, lysencephaly, Alzheimer's disease [8-10]. However, to the best of our knowledge, there is no study targeting the relationship between reelin and suicide.

Therefore, in the present study we aimed to test the relationship between suicide and reelin protein.

\section{Materials and Methods}

This study was conducted after the approval of Firat University Faculty of Medicine Clinical Research Ethics Committee with the decision number 0606 dated 24/03/2015. A total of 86 patients who were suicide attempters and admitted to the Emergency Department of Firat University Medical School Hospital between March 2015 and November 2015 were included in the study and denoted as Suicide Group. In addition, a control group consisting of 100 healthy volunteers was formed and denoted as Control Group.

We initially recorded demographic data from all the individuals in healthy controls (Control Group) and suicide attempters (Suicide Group). We also measured and recorded body mass index (BMI), pulse, and respiration rate of all the cases.

We subsequently assayed blood serum reelin levels of all 186 individuals included in the present study. Reelin levels were assayed in serum samples according to the kit procedures using the Human ELISA kit (Rel Assay. Diagnostics, REF no1; E20160202016, LOT no1; 20160202, REF no2; E20160202017, LOT no2; 20160202). Samples were not diluted. Absorbances were read spectrophotometrically at $450 \mathrm{~nm}$ on ELX800 ELISA reader. In plate washing, Bio-tek ELX50 (BioTek Instruments, USA) was used as an automatic washer. Results were expressed as ng/L. The measuring range was $37 \mathrm{ng} / \mathrm{L}-7000 \mathrm{ng} / \mathrm{L}$ and the minimum measurable level was $15.23 \mathrm{ng} / \mathrm{L}$.

After the data were collected, statistical analyses were performed using the statistical analyses program SPSS 21.0. Kolmogorov-Smirnov and ShapiroWilk normality tests were employed to test the deviations from the normality. Numerical data were expressed as mean \pm standard deviation and qualitative data were expressed as percentages. In addition, data that did not fit into the normal distribution were presented as Median (Interquartile range, IQR). Student t-test was used to test differences between means of two groups with the continuous variables that were normally distributed. Chi-Square test was used to test nonrandom distribution of categorical data among groups. Man-Whitney-U test was used to compare non-parametric paired groups. A p-value of $<0.05$ was considered significant throughout the analyses. 
XXVII. Balkan Clinical Laboratory Federation Meeting BCLF 2019

XXX. National Congress of the Turkish Biochemical Society TBS 2019

\section{Results}

Of the 186 patients included in our study, 86 were suicide attempters and 100 were healthy controls. Among 86 suicide attempters, 52 (\%60.5) were females and $34(\% 39.5)$ were males. The control group consisted of 54 females and 46 males. The mean age of Suicide Group was $28.14( \pm 10.04)$ years and that of Control group was $32.52( \pm 13.71)$ years. We conducted a Chi-square test was used to assess the gender distribution among groups and the results revealed that the difference was not significant $(\mathrm{p}=0.69)$ (Table 1$)$.

Although there was a statistically significant difference between the groups in the mean BMI $(\mathrm{p}=0.001)$, age $(\mathrm{p}=0.001)$, and respiratory rate $(\mathrm{p}<0.001)$, these values were within the limits accepted as clinically normal.

Table 1: Comparison of demographic and clinic data of Suicide Group and Control Group.

\begin{tabular}{lccc}
\hline Parameters & Suicide Group & Control Group & $\mathrm{P}$ \\
\hline $\mathrm{N}($ Female/Male) & $86(52 / 34)$ & $100(54 / 46)$ & 0.690 \\
Age (years) & $28.14 \pm 10.04$ & $32.52 \pm 13.71$ & 0.001 \\
$\mathrm{BMI}\left(\mathrm{kg} / \mathrm{m}^{2}\right)$ & $23.28 \pm 4.47$ & $24.93 \pm 3.38$ & 0.001 \\
Pulse (beats per min) & $90.65 \pm 21.76$ & $84.92 \pm 14.78$ & 0.112 \\
Respiration Rate (breaths per $\mathrm{min})$ & $17.80 \pm 3.17$ & $14.96 \pm 1.20$ & $<0.001$ \\
\hline
\end{tabular}

In our study, the median reelin enzyme level was found to be $3038.31 \mathrm{ng} / \mathrm{L}$ (IQR: 212.46-8044.21 ng/L) in Suicide Group and as $2271.20 \mathrm{ng} / \mathrm{L}$ (IQR: 77.67-7647.83 $\mathrm{ng} / \mathrm{L})$ in Control Group. The difference in the reelin enzyme levels between the two groups was found to be significantly different $(\mathrm{p}<0.0001)$ (Table 2$)$.

Table 2. Comparison of reelin levels in patients attempting suicide and healthy control group.

\begin{tabular}{lccc}
\hline Parameters & Suicide Group & $\begin{array}{c}\text { Control } \\
\text { Group }\end{array}$ & $P$ \\
\hline N (Female/Male) & $86(52 / 34)$ & $100(54 / 46)$ & 0.690 \\
Reelin Enzyme Median (IQR ng/L) & 3038.31 & 2271.20 & 0.001 \\
& $(212.46-$ & $(77.67-$ & \\
& $8044.21)$ & $7647.83)$ & \\
\hline
\end{tabular}

\section{Discussion}

Suicide is an increasing public health problem in our country as well as all over the world [11]. A number of earlier studies targeted the demographic data from the suicide cases in Turkey to deduce the general pattern. Önsüz et al. [12] evaluated 1566 patients with suicide attempts in the emergency department and reported that $78.9 \%$ were women and 1109 of all patients were in the 15-34 age group. In a 10 -year retrospective study, 2988 out of 4569 patients admitted to the emergency department for suicide attempt were female (65.4\%). The study also concluded that the mean age of females was $24.5 \pm 10.1$ years and the mean age of males was $29.5 \pm 13.2$ years [13]. Kara et al. [14] found that $74 \%$ of 1036 patients were females in their study on the evaluation of patients admitted to the emergency department due to intoxication. They also reported that $60 \%$ of all patients were in the 15-24 age group [14]. Ersoy et al. [15] found in their retrospective study that the female ratio was higher $(72.8 \%)$ and the mean age of all patients was $27 \pm 13.8$ years. The demographic data reported here showed similar pattern to the aforementioned literature in terms of gender and age.

An intensive amount of research has been devoted to understanding the biochemical pattern in suicidal patients. However, the role of reelin in the suicide cases has not yet been investigated. Here, we evaluated demographic data from the patients who attempted suicide in respect to reelin levels and found a negative correlation with age and body mass index. In a study on patients with autism, Camacho et al. [16] found that the reelin protein is expressed and stored in CajalRetzius cells developing in the cereal cortex and cerebellum. While these cells are reported to be present in the developing cerebral cortex, most of these cells have been detected to have apoptosis and a very small group of them are alive in the progressed age groups. Therefore, as in our study, the level of reelin was found to be higher in individuals at younger ages [16].

The role of reelin in the innate psychiatric diseases have been investigated in depth. One of the most important mechanism of action of the reelin is synaptogenesis, structural and biochemical neuroplasticity in dendritic endings of axons in the hippocampus in the human brain [17]. Reelin level deficiency is attributed to disruption of neuroplasticity and regulation of gene expression from the endoplasmic reticulum, protein production and their posttranslational modification in peripheral tissues [17]. Similarly, in our study, an inverse relationship was found between the reelin level and body mass index, and it was found that the reelin level decreased as the body mass index increased.
More than 100 markers have been identified in the studies conducted to detect a possible biological marker in the brains of schizophrenia patients and reelin and glutamic acid decarboxylase (GAD) have been frequently studied in this context [18-20]. Both proteins are expressed in cortical GABAergic neurons. While GAD plays a role in GABA synthesis, the extracellular matrix protein, reelin, binds to dendrites and plays a role in long term potentialization, which is important in learning and memory. Low levels of both reelin and GAD1 mRNAs are among the most frequent findings in schizophrenia brains [8,19,21-24]. This suggests that the regulation of the GABAergic system is impaired in schizophrenia. This disorder has been reported to be associated with impaired working memory in patients with schizophrenia [25].

In the study of 10 male and 8 female patients diagnosed with the schizophrenia, Hornig et al. [26] investigated reelin enzyme level while comparing them to a total of 18 ( 9 females/ 9 males) healthy controls. ELISA and Western Blot were used in the study and both methods were compared. In both methods, it was found that reelin enzyme level increased significantly in schizophrenia patients. They claimed that the drugs patients had taken increased the level of the reelin [26]. Similarly, Fatemi et al. found that the concentration of blood reelin in patients with schizophrenia increased compared with the healthy control group [8]. Reelin levels were evaluated in a wide range of neurological and neuropsychiatric diseases such as depression, schizophrenia, Alzheimer's and different results were obtained in each disease. The levels of reelin in postmortem brain tissues were investigated in schizophrenia patients and this enzyme was found to have decreased in patients with schizophrenia. In our study, the blood serum reelin levels were found to have elevated similar to Hornig et al. [26] and Fatemi et al. [8]. However, in both studies, it is stated that there is not enough data to explain the molecular mechanism of the increase.

There is a general lack of empirical information between suicide and reelin. We believe that more conclusive data could be conceived with a wider patient population. In addition, it was concluded that this study will be reference point for the future studies.

\section{Conclusion}

According to the results of this study, reelin enzyme level of suicide patients was found to be significant factor for suicide. The importance and impact of our findings on suicide needs to be investigated and targeting role of reelin in experimental animal studies will be an interesting research venue.

\section{Acknowledgements}

This study was compiled from the thesis presented in Firat University Medical Faculty Emergency Medicine department. The study was financially supported by Firat University Scientific Research Support Coordinator (FÜBAP) (Project No:TF.15.40). We would like to thank FÜBAP for their support.

\section{References}

[1] World Health Organization. Figures and facts about suicide. Geneva: World Health Organization; 1999.

[2] Bondy B, Buettner A, Zill P. Genetics of suicide. Mol Psychiatry 2006;11:336351 .

[3] Mann JJ, Apter A, Bertolote J, Beautrais A, Currier D, Haas A, et al. Suicide prevention strategies: a systematic review. Jama 2005;294:2064-2074.

[4] Kaplan HI, Sadock BJ. The Clinic Psychiatry. Lippincott Williams \& Wilkins, Philadelphia: USA; 2001.

[5] Sadock BJ, Sadock VA, Ruiz P. Comprehensive textbook of psychiatry. vol. 1. lippincott Williams \& Wilkins Philadelphia; 2000.

[6] DeSilva U, D'Arcangelo G, Braden VV, Chen J, Miao GG, Curran T, et al. The human reelin gene: isolation, sequencing, and mapping on chromosome 7. Genome Res 1997;7:157-164.

[7] Lee GH, D'Arcangelo G. New Insights into Reelin-Mediated Signaling Pathways. Front. Cell. Neurosci. 10: 122. 2016.

[8] Fatemi SH, Earle JA, McMenomy T. Reduction in Reelin immunoreactivity in hippocampus of subjects with schizophrenia, bipolar disorder and major depression. Mol Psychiatry 2000;5:654.

[9] Dutta S, Gangopadhyay PK, Sinha S, Chatterjee A, Ghosh S, Rajamma U. An association analysis of reelin gene (RELN) polymorphisms with childhood epilepsy in eastern Indian population from West Bengal. Cell and Mol Neurobiol 2011;31:45-56.

[10] Seripa D, Matera MG, Franceschi M, Daniele A, Bizzarro A, Rinaldi M, et al. The RELN locus in Alzheimer's disease. J of Alzheimer's Dis 2008;14:335-344. [11] Levi F, La Vecchia C, Saraceno B. Global suicide rates. Eur. J. Public Health 2003;13:97-98.

[12] Önsüz MF, Demir F, Afşari EK, Şahin A, Çatalbaş Y, Bektaş H. Sakarya 
XXVII. Balkan Clinical Laboratory Federation Meeting BCLF 2019

XXX. National Congress of the Turkish Biochemical Society TBS 2019

İlinde gerçekleşen intihar girişimi vakalarının değerlendirilmesi/Evaluation of suicide attempts in Sakarya. Turk J. of Public Health 2012;10:141-150.

[13] Satar S, Seydaoglu G, Akpinar A, Sebe A, Karakoc E, Gumusay U, et al. Trends in acute adult poisoning in a ten-year period in Turkey: factors affecting the hazardous outcome. Bratisl Lek Listy 2009;110:404-411.

[14] Kara H, Bayir A, Degirmenci S, Kayis SA, Akinci M, Ak A, et al. Causes of poisoning in patients evaluated in a hospital emergency department in Konya, Turkey. J Pak Med Assoc 2014;64:1042-1048.

[15] Ersoy A, Kara D, Cangir CC, Erdoğan E, Ali A, Büyükyıldırım A. Yoğun bakımda intoksikasyon olgularının değerlendirilmesi. Okmeydanı Tıp Dergisi 2013;29:72-5.

[16] Camacho J, Ejaz E, Ariza J, Noctor SC, Martínez-Cerdeño V. RELNexpressing neuron density in layer I of the superior temporal lobe is similar in human brains with autism and in age-matched controls. Neurosci. Lett. 2014;579:163-167.

[17] Bosch C, Muhaisen A, Pujadas L, Soriano E, Martínez A. Reelin exerts structural, biochemical and transcriptional regulation over presynaptic and postsynaptic elements in the adult hippocampus. Front Cel Neurosci 2016;10:138. [18] Impagnatiello F, Guidotti AR, Pesold C, Dwivedi Y, Caruncho H, Pisu $\mathrm{MG}$, et al. A decrease of reelin expression as a putative vulnerability factor in schizophrenia. PNAS 1998;95:15718-15723.

[19] Guidotti A, Auta J, Davis JM, Gerevini VD, Dwivedi Y, Grayson DR, et al. Decrease in reelin and glutamic acid decarboxylase67 (GAD67) expression in schizophrenia and bipolar disorder: a postmortem brain study. Arc Gen Psychiatry 2000;57:1061-1069.

[20] Costa E, Davis JM, Dong E, Grayson DR, Guidotti A, Tremolizzo L, et al. A GABAergic cortical deficit dominates schizophrenia pathophysiology. Crit Rev Neurobiol 2004; 16 .

[21] Akbarian S, Kim JJ, Potkin SG, Hagman JO, Tafazzoli A, Bunney WE, et al. Gene expression for glutamic acid decarboxylase is reduced without loss of neurons in prefrontal cortex of schizophrenics. Arc Gen Psychiatry 1995;52:258266.

[22] Benes FM, Lim B, Matzilevich D, Walsh JP, Subburaju S, Minns M. Regulation of the GABA cell phenotype in hippocampus of schizophrenics and bipolars. PNAS 2007;104:10164-10169.

[23] Benes FM, Lim B, Matzilevich D, Subburaju S, Walsh JP. Circuitrybased gene expression profiles in GABA cells of the trisynaptic pathway in schizophrenics versus bipolars. PNAS 2008;105:20935-20940.

[24] Hashimoto T, Arion D, Unger T, Maldonado-Aviles JG, Morris HM, Volk DW, et al. Alterations in GABA-related transcriptome in the dorsolateral prefrontal cortex of subjects with schizophrenia. Mol Psychiatry 2008;13:147.

[25] Lewis DA, Hashimoto T, Volk DW. Cortical inhibitory neurons and schizophrenia. Nat Rev Neurosci 2005;6:312.

[26] Hornig T, Sturm L, Fiebich B, van Elst LT. Increased blood-reelin-levels in first episode schizophrenia. PloS One 2015;10:e134671. 